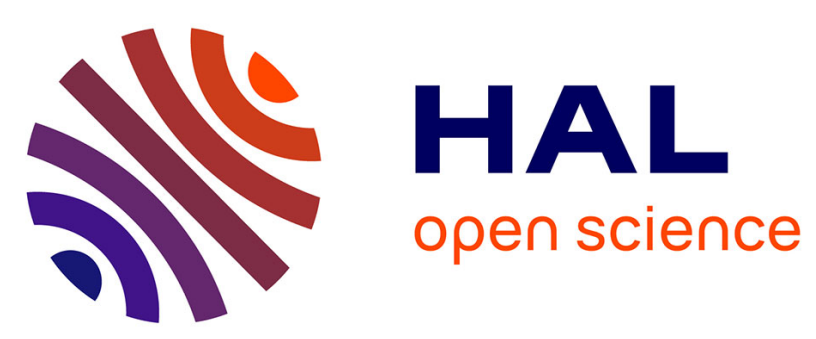

\title{
Is Employee Technological "Ill-Being" Missing From Corporate Responsibility? The Foucauldian Ethics of Ubiquitous IT Uses in Organizations
}

Aurélie Leclercq Vandelannoitte

\section{- To cite this version:}

Aurélie Leclercq Vandelannoitte. Is Employee Technological "Ill-Being" Missing From Corporate Responsibility? The Foucauldian Ethics of Ubiquitous IT Uses in Organizations. Journal of Business Ethics, 2019, 160, pp.339-361. 10.1007/s10551-019-04202-y . hal-03328165

\section{HAL Id: hal-03328165 \\ https://hal.science/hal-03328165}

Submitted on 28 Aug 2021

HAL is a multi-disciplinary open access archive for the deposit and dissemination of scientific research documents, whether they are published or not. The documents may come from teaching and research institutions in France or abroad, or from public or private research centers.
L'archive ouverte pluridisciplinaire HAL, est destinée au dépôt et à la diffusion de documents scientifiques de niveau recherche, publiés ou non, émanant des établissements d'enseignement et de recherche français ou étrangers, des laboratoires publics ou privés. 


\title{
Is Employee Technological "Ill-Being" Missing From Corporate Responsibility?
}

\author{
The Foucauldian Ethics of Ubiquitous IT Uses in Organizations
}

\author{
Aurélie Leclercq-Vandelannoitte \\ CNRS, LEM (UMR 9221), IESEG School of Management
}

\begin{abstract}
The ethical issues introduced by excessive uses of ubiquitous information technology (IT) at work have received little attention, from either practitioners or ethics scholars. This article suggests the concept of technological ill-being and explores the ethical issues arising from such ill-being, according to the individual and collective responsibilities associated with their negative effects. This article turns to the philosopher Michel Foucault and proposes a renewed approach of the relationship among IT, ethics, and responsibility, based on the concepts of practical rationality, awareness, and self-engagement. This article reports a case study of an international automotive company actively engaged in both corporate social responsibility (CSR) and ubiquitous IT deployment. Technological ill-being is an expression of the tension between an individual's social attributes and aspirations when using modern IT and a system of norms, rules, and values imposing constraints on him or her. We identify the reasons for the lack of consideration of technological ill-being in CSR through identification of the inclusion-exclusion principle. The resulting critical, comprehensive approach to corporate responsibilities and IT uses incorporates the ethical implications of the latter, highlights the practical rationality of their relationship, and demands both individual and collective responses, through a call for collective ethical awareness and self-engagement. The findings prompt a Foucauldian ethics of IT use in organizations, which emerges in a mutually constitutive relationship between the self, as a moral subject of own actions, and broader organizational principles, in which CSR appears as a techne (i.e., a practical rationality governed by conscious aims).
\end{abstract}

Keywords: Ethics, Ubiquitous information technology, Corporate responsibility, Technological ill-being, Michel Foucault, Inclusion-exclusion principle

\section{Introduction}

"When was the last time you switched off for 24 hours? If the answer is 'I can't remember' a digital detox could be what you need" (Booth 2014). Unimaginable only a decade ago, "digital detox" experiences have become increasingly popular as ubiquitous information technology (IT) (e.g., smartphones, computers) has become available, wearable, constantly connected, and integrated into people's daily lives. Ubiquitous IT has indeed become the primary means of communication and pervades all aspects of professional and personal spheres (Ayyagari et al. 2011; Dery et al. 2014). It appears as multi-functional devices, allowing for both hedonic and utilitarian use (Steelman et al. 2012), such as texting, making calls, e-mailing, using social media, playing, or browsing the web. With its constant access, 
ubiquitous IT has made it possible to connect anytime, anywhere and to deliver information in real time to individuals and organizations. It is thus highly beneficial for the efficiency of organizations and individuals but also promotes negative-side effects (Tarafdar et al. 2015), stemming from its proliferation, invasiveness, ubiquity, and convenient nature, leading to unfortunate changes in social behavior (Soror et al. 2015):

A reflexive, first act in the morning for two-thirds of ubiquitous IT users is to check their smartphones, and $65 \%$ of them check their work e-mails every five minutes during the day (Laval 2015). A recent report found that, on average, people check their ubiquitous IT 150 times a day (Soror et al. 2015). At work, employees spend an average of $28 \%$ of their time dealing with IT-based interruptions, and managers spend five hours daily on e-mails, with $70 \%$ of e-mails being addressed within six seconds of arrival (Addas and Pinsonneault 2015). When asked, $65 \%$ of employees agree that ubiquitous IT is stressful, due to its invasive effect and the constant social pressure to check for messages (Tarafdar et al. 2015).

The invasion of ubiquitous IT inevitably creates new challenges to ethical standards for social conduct, including unique ethical questions about the excessive uses of IT at work, leading to what we refer to as employee technological ill-being, which, compared with the frequently mentioned notion of well-being, has not been explicitly conceptualized. Aware of the frustrations and stress of his employees due to excessive IT uses, Thierry Breton, the CEO of Atos, a large French telecommunication company, raised in a public statement the question of the responsibility of his company: "We are producing data on a massive scale that is fast polluting our working environment and also encroaching into our personal lives.... We are taking action now to reverse this trend, just as organizations took measures to reduce environmental pollution after the industrial revolution" (Burkus 2016). Thus, in this unprecedented connective context (Kolb et al. 2012), it is crucial to understand whether responsible firms, which pursue ethical choices and corporate social responsibility (CSR), should also address excessive IT uses that can harm employees and lead to their ill-being.

Defined as "the normative responsibility of organizations toward the welfare of others in the community and society in general" (Factor et al. 2013, p. 144), CSR functions as a selfregulatory mechanism, such that organizations monitor and ensure their own active compliance with the spirit of the law and national or international norms by integrating ethics into their practices and applying ethical standards (Rasche et al. 2017). Ethics designates the reflective study of moral values and legal and social issues, including consideration of the moral choices that individuals make in their relationships with others (Herschel and Andrews 1997, p. 160). Both CSR policies and ethical reflections have emerged in relation to various organizational topics, including human rights, corporate governance, health and safety, environmental effects, working conditions, and contributions to economic development and sustainability, spanning a wide range of stakeholders (e.g., customers, shareholders, employees, the community).

However, surprisingly little attention centers on the ethical or corporate responsibility of organizations with regard to the effects of excessive IT uses on employee well-being. While prior research in management of information systems (MIS) has clearly detailed the "dark side" of excessive ubiquitous IT uses (Cunha et al. 2015; D'Arcy et al. 2014; Tarafdar et al. 2013), in the form of information and cognitive overload (Spira 2011), technostress (Barley et al. 2011; Ragu-Nathan et al. 2008; Srivastava et al. 2015; Tarafdar et al. 2007, 2014), or addictions (Serenko and Turel 2015; Steelman et al. 2012; Turel et al. 2011), the ethical issues for employees and possible organizational responsibilities raised by excessive IT use have rarely been questioned. In general, the ethical issues related to technological ill-being have not been recognized, framed, or analyzed as such by business ethicists or practitioners, 
leaving no answer to the question of who is responsible for what aspects associated with the development of such practices.

In general, business ethics literature has not sufficiently addressed the role of "business firms and managers ... in the design, development, and dissemination of technology across communities and within their firm" (Martin et al. 2017). Thus, while at the beginning of the Information Age, "[s]ome observers of modern culture already complained [that] while technology has advanced dramatically, our moral aptitude in dealing with it has not" (Borgman 1992, p. 110), this assertion seems even truer today. Although ubiquitous IT-based communications are both pervasive and intrusive, across work and personal settings, few firms have clear guidelines on what practices and behaviors they should encourage. Therefore, and in response to calls for more ethics research into how organizations and their members should incorporate IT into their everyday communication practices (Drake et al. 2000), our objective is to analyze the ethical challenges raised by technological ill-being at work and the corporate and organizational actors' responsibilities in this regard, along three main research questions:

Q1: How is the reality of technological ill-being framed in organizations?

Q2: To what extent are organizational actors aware of such technological ill-being?

Q3: Who is ethically responsible for employees' technological ill-being?

To answer these questions, we first rely on and adapt Martin and Freeman's (2003) framework to develop understanding of our suggested concept of employee technological illbeing. We then investigate the question of responsibility involved in IT uses (Martin and Freeman 2003) and assess how prior business ethics literature has treated regulations of IT uses by corporations. From this review, we turn to the work of the French philosopher Michel Foucault to conceptualize the relationship among IT, ethics, and responsibility, using the concepts of practical rationality, awareness, and ethical engagement. Our conceptual framework provides a backdrop for exploring an international company (car supplier) involved in ubiquitous IT use and actively engaged in CSR. Our contributions are threefold. First, this research contributes to literature on the dark side of IT and the ethical implications of IT uses, by proposing the concept of technological ill-being and highlighting the absence of considerations of such ill-being as a form of corporate responsibility, which we conceive of as a techne (i.e., a practical rationality governed by conscious but more or less visible aims serving organizational goals). Second, such "un-awareness" of technological ill-being indeed constitutes a purposeful abdication of responsibility (Johnson 2015), emphasizing that codes of ethics, through what we refer to as the inclusion-exclusion principle, act as key means through which organizations try to govern behaviors, thus contributing to the critical literature on CSR. Third, our study suggests, however, that an alternative moral project can be envisaged and proposes a renewed, Foucauldian conception of ethics as a practice of the self, based on ethical awareness and self-reflexivity, engaged in relation to others.

Our findings eventually prompt a Foucauldian ethics of IT use at work, which emerges in a mutually constitutive relationship between the self, as a moral subject of own actions, developed through awareness, strategies of self-reflexivity, and self-engagement, and broader organizational principles, in which CSR is purposefully organized through discursive practices. Finally, we analyze the practical implications and limitations of this study and propose potential avenues for further research.

\section{Employees' Technological Ill-Being Due to Excessive Ubiquitous IT Use}


According to Tarafdar et al. (2015, p. 61), humankind has entered an era characterized by frailties that have begun slowing down progress from digital technologies. In particular, excessive uses of ubiquitous IT raise new ethical questions in work contexts. We propose the concept of technological ill-being to refer to the implications of excessive IT uses for employees. Compared with the frequently mentioned notion of employee well-being, illbeing - a fortiori technological ill-being - has not been explicitly investigated by organization studies and business ethics literature (Cousteaux et al. 2010). To begin characterizing technological ill-being, we rely on Martin and Freeman's (2003) framework, which enables us to gain a better understanding of the potential harmful effects and ethical issues raised by ubiquitous IT uses. This framework helps analyze how such uses may affect the self, relationships with others, and community through their effects on the core interrelated notions of freedom, privacy, and respect (as identified by Martin and Freeman 2003) (see Table 1).

\section{Freedom}

Freedom refers to the basic liberties of any individual. Although ubiquitous IT uses "free" people in terms of access to information and other people (by providing a high degree of independence, mobility, and flexibility), these technologies also possess qualities (connectivity, portability, user-friendliness, and fast processing) that make them simultaneously useful and dangerous to employees' freedom and sense of autonomy. According to the "autonomy paradox", people tend to enact through their uses a "norm of continual connectivity and accessibility", producing contradictory outcomes (Mazmanian et al. 2013, p. 1337) and negative side effects such as a loss of autonomy. For example, the continuous availability of ubiquitous technologies has increasingly turned e-mail into a synchronous medium of communication (Ayyagari et al. 2011; Barley et al. 2011; Capra et al. 2013), triggering widespread interruptions (Addas and Pinsonneault 2015). Other types of excessive IT uses (e.g., instant messaging, connections to social media) have increased people's sense of urgency: perceptions of response times have been modified from the constant connection to ubiquitous IT, while shared behavioral regularities have intensified instant communications and expected responses (Steelman et al. 2012), increasing people's sense of dependence on ubiquitous IT (Koehn 1999; Mazmanian et al. 2013; Tarafdar et al. 2015). Ubiquitous IT uses are thus often associated with behavioral addictions involving excessive interactions with IT and implying a loss of freewill (as buzz acronyms such as FOMO [fear of missing out] and NoMoPhobia [no mobile phobia] reveal). As a response to people's increasing pressures and responsibilities, due to their demanding careers and social obligations, compulsive checking and obsessive use tendencies by employees increasingly occur (Steelman et al. 2012), especially in a context of mobile e-mail (Mazmanian et al. 2013) and social networking websites (Serenko and Turel 2015). Thus, the pervasiveness of ubiquitous IT often results in almost constant IT connectivity, dependence, and loss of autonomy and freewill, as people tend to use their ubiquitous IT almost automatically (Soror et al. 2015).

\section{Privacy}

Privacy refers to employees' private lives and sense of control of their actions. The use of ubiquitous IT at work creates complex situations in which employees' sense of control and privacy are seriously affected, which may have pernicious implications for the overall wellbeing of employees (Tarafdar et al. 2015). The benefits include changes to ways of working, collaborating, and living, but such changes also have non-beneficial, unintended, contrary consequences related to employees' control over their actions, privacy, and work-life balance (Tarafdar et al. 2015). By using ubiquitous IT, employees are no longer constrained by the physical walls of the office, but such technologies also give employees a virtual yet "fixed 
individualized address" acting as an electronic leash (Arnold 2003). Furthermore, with the disconnection between physical and social proximity and between physical absence and virtual presence, distance and (potentially constant) connection implies a blurring of boundaries between work and non-work places and work and non-work times (Arnold 2003), suggesting that there is no possibility for employees to escape work (Dery et al. 2014). The "reaching-out" that technologies provide is always associated with a "reaching-in" (Arnold 2003), in increasingly unexpected contexts and moments, so that at any moment one must be ready and reachable (be it by calling, texting, or e-mailing). Ubiquitous IT is thus characterized by an irony of extension (of work and individual reachability) and invasion of spheres that used to be private and out of reach. Furthermore, the possibility to work anywhere, anytime may induce specific, excessive IT uses through which people, who think they are in debt of the trust given them by their organizations, re-create at a distance norms of availability (Sewell and Taskin 2015) during unexpected moments (in the evening, on weekends, or on holidays) that finally infringe on their autonomy, privacy, and sense of control. Excessive IT uses thus often translate what these employees view as an implicit control of their engagement at a distance (rather than in situ, direct control) (MacCormick et al. 2012). Paradoxically, in many cases, employees seem unaware of such pressures and assume that their IT uses reflect their own deliberate decisions, sense of control, and purposeful strategies to complete their missions (Koehn 1999; Mazmanian et al. 2013), such that they voluntarily create, co-produce, or naturally accept such uses, norms of availability at a distance, and effects, raising new tensions between technology and morality (Bauman and Lyon 2013).

\section{Respect}

Respect refers to the treatment of others as ends in themselves rather than mere means. Ubiquitous IT has a dual nature and performs in Janus-faced ways - that is, ironic, perverse, and paradoxical (Arnold 2003). While they symbolize freedom, mobility, and flexibility in terms of time and place, IT uses raise moral and ethical concerns as they create a specific mindset at work that tends to reduce practical issues to questions of - or even an obsession with-efficiency and control (Koehn 1999), regardless of the individuals affected by such logics. Excessive uses of ubiquitous IT are indeed associated with expectations that people need or are obligated to work faster (Ayyagari et al. 2011) and urgently. They take place in a broader system and organizational culture that tends to reward people who work exceptionally hard, spend long hours at work, and are connected to the organization 24/7 via ubiquitous IT (Ayyagari et al. 2011). Koehn (1999, p. 58) described the adverse ethical consequences of IT for business and professions when "technical skill" supplants the more "professional idea of art" in an analysis that highlights such a seeming cult of urgency, productivity, and efficiency. Ubiquitous IT seems to extend such logics, as it translates into a societal episteme of efficiency (Leclercq-Vandelannoitte 2011) that features a "utilitarian drive of values" and increases distance in any human relationship (Koehn 1999, p. 58). Prior critical research has recognized that any technology can act as a threat and source of exploitation (Cordeiro 1997), leading to employees' degradation of working conditions (Braverman 1974) and alienation (Davies 1997). Accordingly, ubiquitous IT uses may lead to a degradation of employees' well-being, both at and outside work.

In the end, the effects of ubiquitous IT uses on notions of freedom, privacy, and respect (Table 1) combine to produce employee technological ill-being. According to Martin and Freeman (2003), analyses of the effects of the uses of new technologies on notions of 
freedom, privacy, and respect are inseparable from analyses of the responsibilities for such effects.

\author{
[Insert Table 1 about here]
}

Table 1 Synthesis of the impacts of ubiquitous IT uses on freedom, privacy, and respect

\title{
The Sensitive Question of Responsibility
}

\section{Regulating Ubiquitous IT Uses: An Ethical Issue for Managers, a CSR for Organizations?}

According to Markus (1994), any user can influence the norms that emerge from IT use (Drake et al. 2000). In this vein, Martin and Freeman (2003) call for greater understanding of the "value-laden-ness of technology" (p. 359), with the claim that any technology has "embedded values" such that "the decision to internally adopt ... the technologies is a decision to adopt ... those values" (p. 360). Any IT-related decision is above all a decision about the way people want and perhaps ought to live (Davies 1997), so that the implementation of any technology (like ubiquitous IT) first and always appears as a moral decision (Borgman 1992).

Some studies assign responsibility to organizations and managers to retain appropriate values when adopting or using a technology (Drake et al. 2000; Herschel and Andrews 1997; Martin and Freeman 2004). As Factor et al. (2013) recognize, corporate responsibility includes organizations' responsibility for the well-being of any member of their community, such as employees. CSR designates organizational self-regulations about how managers should deal with any social issue (Windsor 2006) according to ethical standards and moral values. Some studies even argue that CSR has been built by businesspeople themselves, as a result of the larger movement of "managerial professionalization", to justify and legitimate their role and social status in the welfare of the whole society (Acquier and Gond 2007; Gond and Moon 2011). CSR relies on ethics (i.e., the awareness that anyone is an intricate link in a broader system), in which anyone's interests are inevitably intertwined with others' interests (Solomon and Hanson 1985). Ethics considers any relationship (as it is and as it ought to be) between a wide range of stakeholders (Herschel and Andrews 1997). It offers guidelines to conduct social behavior in a manner intended to protect and fulfill the rights of all individuals (Marshall 1999). Such guidelines are not simply laws or prescriptions for specific behaviors (as in classic codes of ethics) but also include basic principles of analysis, beliefs, and assumptions about life, individuals, and social values (Marshall 1999). Business ethics research investigates corporate responsibility for different contexts and technologies, suggesting that responsibilities are both individual and collective. Although most research takes an organizational perspective (with the organization as the actor), CSR initially had an individual focus, with Davis and Blomstrom (1966, p. 12) defining social responsibility as "a person's obligation to consider the effects of his decisions and actions on the whole social system".

Business ethics researchers thus highlight the role of organizations in and their managers' moral responsibilities (Wood 1991) for the spread of CSR norms and practices (Factor et al. 2013). This view assumes that "[m]anagers are moral actors. Within every domain of CSR, they are obligated to exercise such discretion as is available to them, toward socially responsible outcomes" (Wood 1991, p. 699). For example, managers may be expected to promote responsible IT uses by adhering to general ethical principles in their relationships 
with competitors, suppliers, customers, employees, and general society (Cordeiro 1997). Research in business ethics has thus called for the development of appropriate norms, codes of ethics, policies, rules, and procedures around newly developed technologies. In this vein, the question of corporate responsibility seems particularly crucial in the context of ubiquitous IT uses at work, especially in light of their potential effects on employees' overall well-being through their consequences on the notions of freedom, privacy, and respect (Martin and Freeman 2003). Far from being neutral, ubiquitous IT uses (probably more than any past technologies; Marshall 1999) have become an integral part of everyday life (Dery et al. 2014), affecting people's world views, social interactions, and relationships with others. They necessarily involve interactions (e.g., managers and employees) and suggest interrelated social impacts on organizations, groups, and individuals. It thus seems particularly acute to analyze the potential responsibilities of management and organizations in the development of such issues (De George 2000) and their ability to anticipate potential risks and ethical issues and keep sight of their effects on organizational members.

\section{A Responsibility Gap: Abdication on Addiction}

Some companies and managers have begun taking such responsibility in IT-related decisions, suggesting their awareness of the pertinent ethical challenges. For example, the need to reduce technological ill-being led Atos to include IT uses as part of its corporate responsibilities. Emails with more than three recipients are banned by Bouygues Telecom, and some companies encourage synchronous and oral communication to resolve problems (Harnish 2014). Both Intel and Volkswagen Germany have instituted "no e-mail days" and issued formal agreements on the acceptable response time frame (Spira 2011). To guarantee "workers' right to disconnect" , the French government recently forbade certain employees from responding to e-mail messages outside normal work hours, and Germany is considering similar legislation.

However, such initiatives remain rare and mostly marginal. The question of the responsibilities and moral duties surrounding excessive uses of ubiquitous IT at work has rarely been addressed, and thus it is not clear whether it is the responsibility of states and governments (e.g., France's legislation and public policies), organizations (e.g., codes of ethics, intervention programs), or each individual (managers and employees who engage in appropriate uses and requests). Furthermore, although excessive ubiquitous IT uses affect employees' freedom, privacy, and respect (Martin and Freeman 2003), their ethical challenges are rarely recognized or framed as such by business ethics literature (Martin et al. 2017; Ottensmeyer and Heroux 1991); similarly, the question of the corporate responsibility involved in such effects is rarely raised as such in organizations. The value of ubiquitous IT uses tends to be measured by first-order effects, in terms of efficiency, impacts on productivity, communication improvements, or returns on investment, while second-order effects, including technological ill-being and its ethical challenges, have been far less studied by business ethics literature or integrated into organizational practices (Drake et al. 2000). Furthermore, even as more research in MIS recognizes the effects of the dark side of IT on employees' well-being (Tarafdar et al. 2015), most organizations focus on the dark side only insofar as it poses risks to employee productivity or innovation or raises legal issues. The organization's interest thus has been the primary motive for considering negative impacts on employees' well-being, not employees' own ill-being or health.

The ethical challenges raised by the uses of ubiquitous IT and technological ill-being for employees are thus characterized by a so-called responsibility gap (Johnson 2015). De George

\footnotetext{
${ }^{1}$ https://www.service-public.fr/particuliers/actualites/A11297.
} 
(1999, p. 263) cites an "abdication of IT ethical responsibility", explaining that though managers know ethical issues exist, they fail to take ethical responsibility for them or expect anyone else to do so. De George condemns such abdication of ethical responsibility as headin-the-sand syndrome, comparing it to the "myth of amoral computing" (Martin and Freeman 2004 , p. 358). The result of this abdication is a failure to accept and assign responsibility (De George 1999). The strong ideologies associated with technologies (considered neutral [Davies 1997] or a source progress [De George 2000]) may explain this exclusion of ethical concerns. Some business ethicists note a lack of understanding of technology's inherently social and moral dimensions (Buchholz and Rosenthal 2002), which tends to keep managers from accepting responsibility for them (De George 2000).

A separation thus arises in analyses of technology versus ethics (Martin and Freeman 2004). Marshall (1999, p. 81), drawing on Ogburn's (1966) thesis, cites an inherent "cultural lag between technology and ethics", such that an irreducible conflict exists between the rapid speed and development of modern IT and the slower speed by which ethical guidelines related to their use (and thus corporate policies to govern their use) emerge. Technological advances arise so quickly and expand so rapidly that the general public has not had time to raise pertinent ethical issues or develop ethical intuitions about their development (De George 2000). It is as if people have lost their ability to reflect on their own behaviors and IT uses (De George 2000). Modern lives are so enmeshed in ubiquitous IT uses (Serres 2015) that people seem unable to recognize the need to examine such uses, communications behaviors, and choices from an ethical perspective (Herschel and Andrews 1997). As a result, few organizations have tackled the ethical issues raised by excessive ubiquitous IT uses, nor do they seem to regard employee technological ill-being as a problem that deserves enough attention to be incorporated into their CSR policies (Fig. 1).

[Insert Figure 1 about here]

Fig. 1 A synthetic view of the abdication of responsibility on technological ill-being

To make sense of the relationship among ethics and responsibilities in IT uses, we turn to the insights of the French philosopher Michel Foucault.

\section{A Foucauldian Approach to the Relationship among Ethics and Responsibilities}

Foucault has long been neglected by business ethics scholars (Crane et al. 2008); yet his work is particularly insightful for both theory and practice of ethics, as it enables new modes of thought and action. Foucault views the task of philosophy as reflecting on the way people should conduct themselves (O'Farrell 2005). He suggests alternative modes of thinking and ways of approaching problems, some of which are particularly insightful for conceptualizing the relationship among technology, ethics, and responsibilities. To better grasp the heuristic potential of such a relationship, it is necessary to go back to the three main axes of Foucault's work: the archeological period, the genealogical period, and "late Foucault", focused on ethics (Burrell 1988). These three axes constitute an integrated framework, whose main ideas support understanding of the dialectic between technology and ethics, the individual and the collective, and the links among three core concepts that are of particular relevance to grasp our research questions: practical rationality, awareness, and ethical engagement. 
Foucault $(1965,1970,1973)$ first examined the social effects of the knowledge produced by discourses and argued that what is accepted as normal, natural, or true in society reflects power relations, which define possible actions and truths. The social world is purposefully organized and normalized in specific ways, such that social reality is framed and conditioned by historical and cultural patterns and immersed in deep power relations. Various institutional mechanisms and knowledge structures (i.e., "apparatuses") enhance and maintain the exercise of power within the social body. Foucault thus uses philosophy and history to highlight the power effect of the discourses that get diffused by social institutions and presented as truthsfor example, madness, prisons, the body, life, death, and human beings have progressively become objects of observation and discursive constructions. Certain behavioral and discursive practices are privileged over others to legitimate authority and induce subtle forms of social control, in a society that has become increasingly disciplinary. In this society, various "technologies" render bodies and minds obedient, docile, and useful, by inducing certain forms of subjectivity, with the goal of disciplining and governing behaviors. Foucault's concept of technology is rooted in "techne" (from Greek), defined as "a practical rationality governed by a conscious aim" (Foucault 1984a, p. 255). This focus on "techne" enables Foucault to explore how power relations operate and to reveal how social reality and subjects are framed and constituted through power relations and practices of subjection. However, by doing so, Foucault essentially intends to enable people (notably the oppressed) to speak for themselves. The human subject is indeed not only passive to the disciplinary society.

Foucault's (1978, 1985a, 1985b) consideration of ethics for and care of the self goes beyond disciplinary technologies of domination to show that different kinds of "technologies of the self" allow people to work on themselves by regulating their bodies and thinking to pursue ethics, whose essential conditions are freedom and the ability to choose one action. Beyond discourses and technologies of domination that attempt to subjectify the individual and assign him or her to specific categories and disciplines, technologies of the self enable this person to develop a better awareness of his or her situation and of the effects of disciplinary procedures. This implies a strategy of reflexivity (Crane et al. 2008), which relies on a better knowledge of the self and of the exercise of power, a critique of what the self is, an analysis of the limits imposed on it, and an experiment with the possibility of going beyond these limits (Foucault 1997, p. 319). Foucault considers it his mission to make people aware of how intolerable some previously taken-for-granted exercises of power actually were and to show them that things could be different (O'Farrell 2005). Foucault presents here an active individual subjectivity that is less constrained by scientific discourse and power relations and more capable, through a deeper self-knowledge and self-awareness of its condition, of working on its self through a self-stylization process independent of subjection practices (Willcocks 2004).

By doing so, Foucault suggests a new form of ethics for people, beyond ignorance of their condition. Such an ethics relies on the ability of individuals to constitute themselves in a desired image, on their capacity to identify the factors preventing or limiting their awareness, and on their inherent willingness to do so. Foucault (1978) considers modes of subjection, through which agency occurs. He recognizes individuals as moral agents, responsible for their own behavior and able to find satisfaction in constraining situations through ethics, technologies of the self, and care of the self (Foucault 1985a, 1985b). Technologies of the self enable people to produce themselves and govern both their own behavior and that of others (Ibarra-Colado et al. 2006). The individual thus reflects the personal space from which human agency emerges, through active, passive, regulated, and resistance possibilities (Willcocks 2004). People thus are freer than they feel (Starkey and Hatchuel 2002). By allowing individuals to reinvent modes of being and developing renewed forms of ethical self- 
engagement, implying novel forms of self-definition, self-discipline, and self-constraints (Crane et al. 2008), Foucault (1985a, 1985b)'s later work supports a reconsideration of ethics, pleasure, and desire in organizations, as well as a renewed view of the relationship between individuals and collective action at organizational and social levels (Starkey and Hatchuel 2002). Technologies of the self and renewed forms of ethical engagement are always engaged in a collective discussion and a mutual care for the self and others. Ironically, while Foucault is mostly famous for his notions of control and disciplinary society, his work is above all a quest for freedom (Willcocks 2004). Foucault (1983, p. 216) indeed stresses the need to "free thought from what it silently thinks and so enable it to think differently", such that "[m]aybe the target nowadays is not to discover what we are, but to refuse what we are".

This framework is insightful in its novel approach to ethics. Far from a moral theory stipulating universal criteria for evaluating people's actions, Foucault's conception of ethics consists of a collection of practices through which people turn themselves into ethical subjects (Crane et al. 2008; Dey and Steyaert 2016). Foucault (1985a, 1985b) recognizes individuals as moral agents, aware of their moral conduct and responsible for their own behavior through ethics. Because technologies of the self develop alongside technologies of domination, people can creatively establish their selves as active moral subjects of their own actions within fields of disciplinary practices. Foucault thus invites each individual to develop an ethical engagement, in particular with technology. The essential condition for the practice of ethics is freedom; ethics is the "conscious practice of freedom" (Foucault 1984b, p. 284), and this freedom is both located and constituted in power relations (Ibarra-Colado et al. 2006), within and contrary to the constraints of the particular regimes of truth that people inhabit. Ethics thus can be conceived of as a critical and creative practice framed within the limits imposed by the exercise of power (Dey and Steyaert 2016). In turn, Foucault (1985a) suggests four aspects related to how "the individual constitutes him/herself as the moral subject of his or her own actions. The first aspect relates to the part of the individual which acts as the focus of moral conduct. The second aspect concerns what makes an individual recognize their moral obligations. The third aspect relates to the means by which individuals transform and work on themselves. The fourth aspect concerns what sort of person an individual might want to be".

Furthermore, in this view ethics means the kind of relationship a person has with him- or herself and with others. Thus, care of the self is always intertwined with care for others (Foucault 1985b). Foucault (1985b) views ethics as relationships between forces in which diverse modes of existence and ethical projects confront each other. This reflection is particularly valuable in terms of how the ethical self emerges in relation to others (Crane et al. 2008) and to the social, organizational, and broader discourses, rules, norms, and techne whose purpose is to determine what a person should be and how he or she should act (Dey and Steyaert 2016; Ibarra-Colado et al. 2006). Foucault tries to understand the ethics and ethical self-relationships that individuals and groups develop in practice, relative to discursively constructed norms (Loacker and Muhr 2009). His view thus locates ethics between individual morality and organizationally prescribed principles, assumed to govern the actions of those individuals (Ibarra-Colado et al. 2006), such that the self is both a target of the exercise of power and the condition for acting differently (Crane et al. 2008). Foucault's (2008, p. 186) vision, or "method of decipherment", thus provides a novel way to address the recent call from business ethicists to be more reflexive, to challenge, both individually and collectively, uses of technology, and to search for an ethics for the technological age.

The Foucauldian approach provides a new entrance point to the debate on the ethical aspects of ubiquitous IT uses at work, as it is related to conceptions of ethics, freedom, and responsibility in acting in specific ways. It first allows for a reconceptualization of the practical rationality and underlying power relations behind specific organizational practices, 
such as CSR, and a better understanding of the consideration of the potential effects of ubiquitous IT uses, such as technological ill-being, in organizational practice; second, it reinvigorates awareness of such practices through strategies of reflexivity; third, it questions responsibilities in IT use and invites critical and ethical self-engagement, in relation to a broader, collective reflexivity (Table 2). We apply this conceptual framework to an illustrative case study, to offer an empirical exploration on the key topics.

\section{[Insert Table 2 about here]}

Table 2 A synthesis of the heuristic power of Foucauldian concepts to grasp the relationship between ethics and responsibilities

\section{Case Study: Research Method}

\section{Research Design}

We use an "instrumental case study" (Stake 2003, p. 137), based on a larger project on ubiquitous IT uses, as an empirical example to better understand the ethical effects of excessive uses of ubiquitous IT at work and the corporate and organizational actors' responsibilities for these ethical challenges. The case study technique offers a research strategy, which aims to understand the dynamics and underlying processes of certain phenomena (Eisenhardt 1989). Case studies offer rich, solidly grounded descriptions and explanations of a process anchored in a local context (Miles and Huberman 1994), so this research method is appropriate for our purposes. In particular, "instrumental case studies" are examined mainly to provide insight into broader issues and play a supportive role in that they facilitate and advance understanding of such issues (Stake 2003). The case was purposefully chosen by the author, who had observed, during this larger project, the emergence of unfortunate changes in employees' social behavior due to the ubiquity and convenient nature of IT. We aim to illustrate and understand, through this exploratory concrete example, how organizations and organizational actors do, can, or should adopt ethical choices when deploying ubiquitous IT at work; take responsibilities for using these technologies in ways that potentially lead to technological ill-being; and have a moral duty to act and regulate such behaviors and the circumstances in which they do so. Our review of the relationship among IT, ethics, and corporate responsibility, coupled with our Foucauldian framework, provides a theoretical foundation for organizing our data collection and analysis, as well as interpreting our findings.

Our exploratory qualitative study involves a large, international company operating in the automotive industry, which we refer to as "Automotive Group" to maintain its anonymity. We conducted this research between January and September 2014, which has been regularly updated since then from the contact maintained by the researcher with members of this organization. This company, a worldwide supplier of technology for cars, works with various car manufacturers on a dynamic market characterized by strong demand and fierce competition with both larger supplier companies and smaller companies that specialize in specific areas of car construction.

This organization is particularly suitable for our research purposes for four reasons. First, its senior-level organizational managers and salespeople regularly use ubiquitous IT, which is 
essential for executing their professional roles, which mostly entail information-based tasks (i.e., reading reports; collecting information; and communicating with clients, peers, managers, and subordinates in different countries) (Pinsonneault and Rivard 1998). The company has assigned state-of-the-art ubiquitous technologies (smartphones and laptops) to them, due to an innovation strategy encouraged by the CEO, who prioritizes cutting-edge IT. All processes in this company are dematerialized, and employees rely on ubiquitous IT such as e-mail, enterprise social networks, instant messaging, shared agendas, scheduling, and a knowledge-based system to perform their daily activities (e.g., data access, diverse applications, such as reporting, billing, holiday, and pay). Second, given the geographic dispersion of its various units and stakeholders, the company has adopted original organizational patterns and working arrangements for its managers and sales employees, who usually work outside the office and headquarters (e.g., the company encourages telecommuting or work in what it internally labels the "virtual office" for managers). Such working arrangements are accompanied by the application of a management-by-objectives system. Third, the organization has engaged in important CSR development focused on sustainability, environmental effects, and working conditions. Fourth, its international dimension provides a rich observation context, in that we can compare differences across legal settings and applications within the company in terms of CSR and regulatory contexts.

\section{Data Collection}

Our empirical research relies on different kinds of data, to ensure triangulation (Table 3 ). The primary data consist of semi-directive interviews and direct field observations, which we used to gain a deeper understanding of the empirical situation. During several months, we observed work and communication practices and ubiquitous IT uses by a commercial team, whose 16 members were located in different European countries and led by a manager (director for several client accounts in Europe) (Fig. 2). To obtain alternative views of their day-to-day work and communication practices, we conducted 14 semi-structured interviews (face-to-face or by telephone) with the manager and employees, as well as with other managers (directors of business units) at different points in time. We focused on their work practices in interactions with various stakeholders (e.g., clients, team members, other internal stakeholders); the goal was to describe how they used ubiquitous technologies to support such practices. Later, we asked each member of the team to provide a written report of a typical workday, describing the number, length, goals, initiatives, interruptions, and consequences of all their IT-based communications. To complement this understanding of the situation, we interviewed other managers (e.g., managers of other business units), the CSR manager, the IT manager, and the human resources (HR) manager, who provided insights into the corporate and managerial visions of CSR policies, technology uses, and the goals and values associated with specific technologies. Follow-up informal interviews and meetings with groups of respondents were organized to check for possible evolutions of practices and perceptions, as well as to gather feedback after additional findings had been collected and shared.

[Insert Figure 2 about here]

Fig. 2 Organizational chart of the respondents

As secondary data, we collected internal documents related to the CSR policy (e.g., "code of ethics and conduct") and revisions to internal charts after the interviews, after noting some recent shifts in the national regulatory contexts. Such documents and press reviews helped contextualize and update our findings and observations. 
To prepare interview guides for each type of respondent, we relied on our literature review and the different functions these respondents performed. Every interview began with a promise of anonymity, followed by general questions (e.g., respondent's function, role, and responsibilities). It then moved to wide-ranging, open topics linked to the respondents' work practices and uses of ubiquitous IT at work to support their activities. We focused on the explanations they used to justify their deployments and the goals they pursued through specific uses of the technologies. Other questions related to the technologies' effects on their activities, practices, communications, work-life balance, and consequences in terms of freedom, privacy, and respect (Martin and Freeman 2003). Further questions pertained to the values, moral aspects, and ethical considerations or awareness of potential ethical issues associated with uses and effects of these technologies. We asked finer-grained questions about perceived responsibilities (at individual, managerial, and organizational levels) involved in technology uses and effects (Martin and Freeman 2003). We also questioned respondents about their perceptions of the CSR policy developed by the company (origins, covered domains, inclusion or exclusion of IT-related issues, values, and objectives). In particular, we asked for their perceptions of the relationship between IT uses and ethics and the possible inclusion of issues of technological ill-being in the company's CSR policy. Our previous observations, which revealed the corporate setting and work practices, provided both background information for the interviews and a means to validate these responses.

[Insert Table 3 about here]

Table 3 Synthesis of collected data

\section{Data Analysis}

Our qualitative analysis relies on abductive reasoning, which aligns the conceptual (deductive) and empirical (inductive) realms of research (Dey and Steyaert 2016; Dubois and Gadde 2002). On the one hand, in accordance with deductive principles, we analyzed the ethical effects of ubiquitous IT uses at the Automotive Group on the core notions of freedom, privacy, and respect (Martin and Freeman 2003) to specify our notion of technological illbeing. We also use Foucault's conceptual entities as a conceptual lens to make sense of the findings and identify important topics, related to the practical rationality for the organizational ethical policy and consideration (or neglect) of the effects of ubiquitous IT uses; we analyzed questions of awareness of the ethical consequences and moral choices behind such uses and effects; and we investigated the responsibilities for IT use. On the other hand, in accordance with inductive perspectives and as expected, other topics emerged from our collected data (i.e., field notes, transcribed interviews, and internal documentation), which we subjected to qualitative content. Following this abductive approach, we developed a thematic coding procedure and created tree nodes (reflecting our literature review and its main constructs) and free nodes (emerging from the textual corpus), according to a three-step procedure (Richards 2005) (Table 4).

[Insert Table 4 about here]

Table 4 Synthesis of the thematic coding procedure

\section{Findings}


Our results are structured around our three research questions and interpreted through our Foucauldian conceptual framework.

\section{Q1: How Is the Reality of Technological Ill-Being Framed at the Automotive Group?}

\section{A Strong CSR Policy, without IT and Technological Ill-Being as Plausible Ethical Issues}

As an international company, Automotive Group has developed ethical reflections since the early 2000s, which are apparent in the company's strong consideration of and compliance with human rights (i.e., commitment to global declarations of rights, economic cooperation, and development). Developed under the aegis of a CSR director, its CSR policy aims to demonstrate the company's willingness to engage in continuous dialogue with stakeholders, respect for strict compliance with legislation, development of a safe working environment, fight against corruption, and environmentally and socially responsible commitments. Since 2010, it has relied on a code of ethics and conduct, established and developed by its Ethics Committee (consisting of internal and external professionals in corporate responsibility and labor and legal issues), approved by the board of directors and reviewed on a regular basis. This code is a mandatory corporate standard, with responsibilities shared by all members of the company, which asserts that compliance with the code is a condition for forming part of the team of professionals. This code is shared with any entity that maintains a business relationship with Automotive Group. By undertaking ethical reflections on various aspects of its business and integrating them into its CSR policy, Automotive Group strives to ensure ethically responsible behaviors by all its members and toward all its shareholders. Among its main values, the company aims to promote "integrity, responsible environmental behavior, respect, confidentiality and privacy of information, wellbeing, health and safety, responsible use of resources, quality in management, image and reputation, absence of conflicts of interests, and a culture of collaboration and management", as noted in the code of ethics.

Through its strong ethical reflections, Automotive Group hopes to ensure its sustainable future and define the impact of its activity on the environment, people, and the social sphere in which it operates. By considering such issues, the company has embraced diverse aspects of an ethical, social, and environmental approach. The company views its code of ethics as a reflection of the values it has developed since its creation; it even cites ethics and CSR as among its main pillars of progress (along with innovation, financial strength, and internationalization). As explained by the CSR director, the CSR policy is also an indirect way for the Automotive Group to compensate for potential negative externalities related to its inherent activity (car manufacturing), which has not always benefited from a positive image in society (more often associated with pollution), and to prove its contribution to social welfare. The CSR policy precisely emerged and was discursively emphasized in the overall organizational strategy as the company's executives began thinking about the perception of their business activities in the eyes of their main stakeholders, notably clients (car constructors) (Gond and Moon 2011), and also in comparison with their main competitors that had developed such policies. As Commercial Director B explained, "having a CSR strategy is a request from the market, dictated by our clients, our suppliers, the law, the general public. It is part of the communication of any company in our field, to give the best image ... to show we can be super-efficient but have a sustainable growth at the same time. We cannot exist in the long term without it, it gives credibility to our actions". One of his colleagues similarly compared the CSR policy to a "marketing tool" that "does not necessarily aim at being formally implemented" but whose "goal is mainly to generate a specific image or marketrelated benefits" and build general social acceptance. 
The Automotive Group notably highlighted its advances in CSR developments and ethical reflections, out its desire to preserve its "human capital" and provide fulfilling working conditions. This respect for ethical standards is at the heart of the organization's policy, so responsibility for the welfare of the community is clearly recognized and promoted, thus enhancing the legitimacy of the organization to its main stakeholders. As part of its CSR policy, the code of ethics and conduct explicitly states that employees' well-being is central to the company's ethical considerations and corporate responsibilities.

Yet, in line with our literature review (Martin et al. 2017) and evidence from the real world, as of January 2017, Automotive Group had not deemed IT effects on employees (i.e., the adoption, design, and use of specific IT) as pertinent, specific ethical issues in its code or as part of its CSR policy. Internal documentation related to ethics and CSR cites "information and communication systems" only twice - referring to a willingness "to eliminate the risks of errors, with a material impact, in financial information" and to "data protection". As the CSR director explained, the CSR policy is more "oriented toward the outside, external world, than to the inside world" constituted by the employees. When it comes to employees, the CSR policy's practical rationality is essentially intended to control their actions to ensure they behave ethically according to the corporate standard (Weaver et al. 1999) - for example, by respecting confidentiality and privacy of information when dealing with IT.

Thus, there was apparently no need to include ubiquitous IT uses in the CSR policy, as respondents shared the idea that ubiquitous IT did not raise any specific problems internally that required ethical considerations or additional specifications in the code of ethics and conduct. They did not mention spontaneously excessive uses of ubiquitous IT or its possible results such as technological ill-being. Rather, they described the ubiquitous IT they use as a source of progress, in that it constitutes "supporting tools", designed to facilitate their daily activities, as summarized by an IT manager: "These technologies are a help, a tool, like we have tools and molds to build our pieces, we have technological tools to help us build our communications". When explicitly asked about excessive uses of IT or informed about the reality of technological ill-being at a societal level, the managers we interviewed demurred and agreed "that is not really a problem at [Automotive Group]" (Commercial Director A). Accordingly, the commercial directors and sales managers we interviewed initially saw no need to include IT uses and the potential negative effects of excessive IT uses in the company's code of ethics and conduct. Similarly, they did not consider it necessary to involve the HR department in technology-related issues, because "It's simply a technological choice, I don't think there is anything human, social, or ethical in this kind of decision" (HR manager). This discourse was widely shared among respondents, who found no problem, at first sight, in their uses of technologies and thus did not frame technological ill-being as a legitimate ethical issue. However, our observations in the field showed that the reality of technological ill-being (observed through effective work, communication practices, and informal discussions) noticeably differed.

\section{Q2: To What Extent Are Organizational Actors Aware of Such Technological Ill-Being?}

\section{From Un-Awareness and Denegation to a Recognition of Ubiquitous IT Uses in Practice Calling Ethics to Mind}

All respondents recognized that ubiquitous IT had changed the way they worked; notably, it had altered traditional spatial and temporal boundaries in the past few years. Yet those changes emerged almost invisibly, because the introduction of ubiquitous IT and its potentialities for work was progressive. Most respondents, offered the option to telecommute and work almost anywhere, are managed "by objectives" and recognize that "it would have 
been impossible to work in the way they work now fifteen or ten years ago"; a salesman further clarified that "working virtually, I mean in a virtual office, from the company premises, at home or anywhere else, is a fantastic opportunity that we couldn't have benefited from some years ago, enabled by the technologies that are currently at our disposal". Another salesman noted, "these technologies are great, since they allow us to access any information and any person, client or colleague, when and where we want". Thus, flexible working opportunities, efficiency, and productivity were frequently cited to describe the effects of deploying these technologies and the reasons to do so. Our interviews and observations in the field also revealed some distinct voices or behaviors though, revealing the potential effects of ubiquitous IT uses on employees' sense of freedom, privacy, and respect (Martin and Freeman 2003).

When asked to reflect on the effects of ubiquitous IT on their freedom, some salespeople began recognizing that they were confronted with constant pressure from their clients, due to the strong competition of their business, which directly translated into specific practices in their ubiquitous IT use, which occurred almost "automatically". Citing addictive behaviors and associated increased stress, a saleswoman stated, "progressively it has become a habit to check our smartphone every five minutes!" One of her colleagues explained that sometimes he was convinced his smartphone had rung (to signal a call) or received a notification (to signal a text message or e-mail), which led him to check his device almost immediately, while in reality this was not the case: "in that case I really have the feeling I'm becoming mad or at least addicted!" Most salespeople and sales managers actually expressed implicit regret about such an evolution of their IT uses, recognizing their "excessive connectivity dependence" and "too many interruptions of activity at work". A salesman said that "it has become almost too easy to communicate by sending e-mails with smartphones; paradoxically I don't think we communicate in a better way, since it seems there are too many, unnecessary communications, and more miscommunications than in the past". Many respondents explained how their uses ended up creating collective expectations of accessibility and availability, as stated by a sales manager: "the possibility to communicate fast creates a demand for instant gratification. The more we send messages, the more we expect a quick answer. It's an escalating process".

Yet some respondents still consider such uses the result of their own deliberate choices (Mazmanian et al. 2013), not social obligations to conform, such that only a few seemed really aware of their role in the co-production of such constraints and invasion of their own privacy. For example, a commercial director noted that "at the beginning, when I started being equipped with my smartphone, I was very happy when I realized that I could receive my emails so simply on this device.... But over time, of course it has progressively, invisibly, and, I would say, insidiously invaded my professional life". That is, respondents did not spontaneously mention the negative aspects of their IT uses, but most implicitly referred to some tensions between their personal aspirations and their embeddedness in a broader system of collective expectations leading to excessive uses and negative consequences on their privacy and loss of sense of control of their own actions. For example, some expressed concerns when disconnected from their smartphone during private moments over the weekend or on holidays, which also affected their work-life balance. A sales manager, for example, recognized that he was often "led to use his smartphone for work reasons in non-appropriate moments, instead of spending time with family.... Sometimes I know I shouldn't do it in front of my children, but it's difficult to do otherwise". As one salesman similarly suggested, "I would say that my family is the main 'victim' of my smartphone". The remote work and flextime tended to insidiously tether these employees, almost around the clock, to their devices and workplaces, even at a distance and in private moments, despite their inherent 
aspirations. Some employees also described how, paradoxically, they intentionally took part in the constitution of such pressures and "burden of representation" (Cunha et al. 2015) by purposefully revealing their connection during the day (e.g., signaling their presence on communication software right after they woke up, sending e-mails at unexpected moments), to reassure management that they could be trusted in terms of their effective activity and productivity even at a distance.

In the end, such uses, which are largely embedded in a cult of efficiency and urgency, regardless of the individuals affected, seemed to have an impact on the sense of respect of the employees. Such attitudes suggested the emergence of more subtle forms of control, beyond traditional "management by objectives", in that engagement with the company becomes manifested and perceived by employees as the potential object of supervision and control. In turn, some employees expressed concerns about what they considered not a mere cult of urgency anymore but a "culture of immediacy", as stated by a salesman; another employee realized that "it is more and more difficult to deal with such a quantity of messages and information. It never ceases.... On the contrary ... I think we are all overwhelmed by such a mass of information, but I don't see unfortunately how we could change the situation".

Excessive ubiquitous IT uses thus extend communication and affect work practices in ways that potentially affect employees' freedom, privacy, and respect. Such behaviors and uses are neither new nor surprising, but they increasingly induce technological ill-being for employees, who end up being caught up in contradictory tensions between their own aspirations and an invisible system of collective expectations and norms imposing constraints on them; such practices are further developed without any clear awareness, explicit notice, or ethical consideration from both employees and management. When we presented the explicit potential for harmful effects to the sales managers, commercial team, HR, and CSR directors, they agreed that the organization and its management had not set any clear guidelines about what is allowed or which behaviors should be encouraged or not, but they also did not consider such uses problems, recognizing that they all faced similar issues, as these technologies were part of their lives and bundled into a broader system. The collective sense that emerged from these observations and interviews implied a common fate shared by all, as summarized by one salesman: "We are all in the same situation. We all have these technologies ... it's a very common problem you know ... in all companies all over the world. It's not really a problem I think". Others suggested that they were all so enmeshed in technologies, for efficiency and performance reasons, that they did not really have time to "take a step back" or "carefully think about the meaning and consequences of our uses of these IT". Notably, these respondents consistently referred to their uses as the result of collective behaviors (even during individual interviews), as shown by their frequent recourse to use plural pronouns such as "us", "we", and "our" or "the system". The members of Automotive Group, probably like those of most companies, acted as if the shared and collective problem of technological ill-being was not a problem at all because of its generalization and the difficulty of doing otherwise as a collective.

\section{Q3: Who Is Ethically Responsible for Employees' Technological Ill-Being?}

\section{On the Implicit Emergence of Ethical Self-Engagement and Collective Reflexivity}

When explicitly questioned about the absence of ethical considerations surrounding such technological ill-being, members of the directorate asserted that it could not be the role of the organization to regulate "individual IT uses"; it is not the goal of a CSR code of ethics to deal with "local or internal issues" such as those "linked to the uses of specific communication tools". These explanations, together with our analysis of internal documentation, indicated 
that corporate responsibilities were mostly (or only) concerned with issues that have some "visibility" in the community or at the societal level (e.g., sustainability, environmental issues). As Commercial Director C explained, "I understand these concerns. But corporate responsibilities cannot be engaged for simple uses of technologies that are part of our life, of our way of working and of living, and that are completely accepted as such". During an informal discussion, another commercial director also explained that though IT uses can have harmful effects, such "consequences don't have and will never have the force of scandals", like the environmental, financial, or human rights (e.g., child labor) concerns that prompted the need for strong CSR policies in the past. As another commercial director noted, "With IT the situation is different; their uses can be negative, very harmful for the individual, and we all know that, but their effects are far more diffused, generalized, invisible and completely integrated and accepted". He added, "it cannot be the mission of the organization, and I am not sure it would be efficient, to protect employees from such effects", reinforcing the idea that CSR policy is mostly oriented to the outside world.

Yet, in one of the countries in which the group operates (France), the government passed a labor law in August 2016, taking effect in January 2017, that gives "employees the "right to disconnect' from e-mail, smartphones and other electronic leashes once their working day has ended" (Petroff and Cornevin 2017). This law mandates that organizations with more than 50 workers begin negotiations to define the rights of employees to ignore their smartphones (Agence France-Presse 2016). The French branch of the Automotive Group thus enacted a new chart and practice guide in early 2017, to ensure employees' right to disconnect and detail the modalities of the application of this legislation, exclusively for the French branch. The new chart highlights good practices to avoid technological ill-being; for example, it encourages employees to think carefully about the need to send an e-mail rather than rely on other communication channels, limit the number of recipients copied on an e-mail message, use the "urgent" flag only when necessary, indicate a clear goal, and question whether it is appropriate to use instant messaging and expect an immediate response or send a message to or call a colleague outside working hours.

Despite the presence of this initiative, to comply with France's regulatory context, this local regulation process was not intended to spread to a more general application to be deployed in other countries or the whole group worldwide. The HR manager confessed that the "organization should not govern and take responsibility for such uses; it would be too complicated, except when we are obligated to do so by law. I think in $99 \%$ of worldwide companies, this problem is not considered as such, except in some case.... Yet, solutions definitely need to be found".

Actually, responsible uses began emerging more at the individual level, through the logics of self-discipline and ethical self-engagement. For example, Commercial Director A explained that "given the strong possibility of drifts with IT uses, it is essential for the manager of a team to be exemplary", and he cited the following example: "I like working on Saturday mornings, I take some hours to answer all the e-mails I don't have time to do during the week. But I've noticed that people in my team tended to answer almost immediately. So I have decided to postpone - on purpose - sending these e-mails until Monday morning, to ensure that people on my team won't be affected or feel pressured to answer immediately". A sales manager also explained that he had stopped using instant messaging because he found it "too intrusive" and that it "could be perceived as an indirect means of control of the presence of his salespeople".

The notions of discipline and self-engagement were shared by other managers, who emphasized the importance of establishing an "ethical climate of communication" in which 
ethical behaviors are taken seriously and actively encouraged, such as by limiting unnecessary communications. Similar terminology (i.e., "self-discipline") emerged to refer to this kind of self-regulation at the managerial or coworker level. One commercial director stressed the need for all managers to be alert to this topic and to take measures on their own to cope with the potential stress associated with communication, by instilling a similar sense of self-discipline throughout their teams. Explaining that he had "the chance to work in an open-minded company receptive to such ethical issues", he highlighted the "possibility to improve, maybe in the future, the code of ethics to integrate more specific items related to moral or ethical ITbased conducts", as in France. Yet he also believed the ultimate objective should be to "change each individual's behavior", by encouraging each employee to decide reflexivity about his or her own uses and effects on others and making them all responsible and accountable for such uses not only for themselves but also for others. Commercial Director B similarly stated, "We have kind of lost our ability to think about our IT uses and their consequences. I think it is the role of each of us to take some time and perspective to understand whether we are harming others and ourselves by acting or communicating in the way we are".

\section{Theoretical Implications}

Our case study offers only one illustration of the ethical concerns raised by the harmful effects of ubiquitous IT uses. Yet, by embracing a Foucauldian approach, it helps us explore the ethical challenges raised by technological ill-being and provides several theoretical contributions related to the absence of considerations of technological ill-being as a form of corporate responsibility. In this section, we present the theoretical implications of our findings, which are interpreted through our Foucauldian conceptual framework along our three research questions, respectively.

\section{Implication 1: Technological Ill-Being-A Neglected Ethical Issue in CSR Policies Conceived of as a Techne}

Our case contributes to the literature on the dark side of IT (D'Arcy et al. 2014; Tarafdar et al. 2015) and on the ethical implications of technological advances (Herschel and Andrews 1997) by exploring the ethical challenges raised by excessive uses of ubiquitous IT at work through the elaboration of the concept of technological ill-being. Even with increased awareness of the dark sides of ubiquitous IT uses in society (Tarafdar et al. 2015), their effects on employees' ill-being and their ethical challenges have not been deeply analyzed so far in business ethics literature. The findings suggest that technological ill-being is an expression of the tensions an individual feels when using modern IT, in relation to the community, as he or she is caught up in contradictions between his or her social attributes and aspirations and a system of norms, rules, and values imposing constraints on him or her (Fig. 3). Technological ill-being affects the basic liberties of users, their sense of control and privacy, and notions of respect of employees (Martin and Freeman 2003), and as such, it inevitably raises the question of the responsibilities and moral duties that organizations and organizational actors have for encouraging or regulating excessive uses of IT, which have the potential to harm employees.

[Insert Figure 3 about here]

Fig. 3 A synthetic view of technological ill-being

Yet, as our empirical study illustrates, technological ill-being is usually not framed or analyzed in organizations as an ethical issue that needs to be considered within CSR policies 
or codes of ethics (except in France, to comply with a new law). The Automotive Group case shows that managers regard technological ill-being and its potential harmful effects as localized, individual, or internal consequences for some employees, without any broader consideration of the value system these technologies promote or their effects at the community level (Martin and Freeman 2003).

In this way, by highlighting the neglect of technological ill-being as a legitimate ethical issue in corporate policies, this study also contributes to literature on ethics and CSR (Rasche et al. 2017). It suggests an analysis of what CSR includes and excludes and covers and does not cover, which provides new insights into what function CSR really performs. In the case of the Automotive Group, more than a concern with or self-regulation for the well-being of any individual member of the community (e.g., employees) (Factor et al. 2013), CSR appears as a techne (Foucault 1984a) - a practical rationality governed by conscious but more or less visible aims (e.g., to show the organization's societal engagement, compensate for possible negative externalities or societal consequences for business activities, as in our case, or establish a reputation for responsibility as an intangible asset; Gond and Moon 2011). The CSR policy is thus purposefully organized through discursive practices (Foucault 1965, 1970, 1973) designed to comply with visible ethical standards that are publicly, collectively recognized as such, to enhance the organization's legitimacy and create a façade of social responsibility (insofar as the CSR policy is intended more to promote value-based principles and construct social acceptance than to be formally implemented, as indicated in the case) (Gond et al. 2009).

As our case shows, CSR aims to create an image, displayed to society, of the organization's concern for and consideration of visible, external, and societal factors that involve large communities or groups (e.g., green issues) and have large impacts (e.g., scandals), rather than internal, less visible, and individual issues (e.g., technological ill-being), for which inclusion in CSR policies is not spontaneously evident or useful. That is, IT-based issues are deemed local, specific, internal problems at the individual level that do not really matter for the organization as a whole and that are not considered legitimate, despite their obvious interconnectedness with the larger collective and the collateral social consequences at the community level.

\section{Implication 2: Technological Ill-Being Unawareness as a Purposeful Abdication of Responsibility}

Furthermore, although Automotive Group is not aware of, or more precisely does not officially recognize and include, the ethical effects of ubiquitous IT uses, our case reveals that there is a conscious decision (Foucault 1984a) for this absence or neglect of technological illbeing considerations. To use Johnson's (2015) term, this "un-awareness" constitutes a purposeful, though unconscious, abdication of responsibility, which benefits the organization, in terms of employees' efficiency, availability, indirect control, productivity, and engagement. Moreover, as the case shows, when IT-related aspects are mentioned in the Automotive Group's CSR policy and code of ethics, they are not intended to empower employees or address their well-being, but to standardize, normalize, and control their IT-based behaviors (Foucault 1979) through compliance-oriented programs (e.g., to ensure correct use of data) (Weaver et al. 1999).

Our findings thus further contribute to the critical literature on CSR (Banerjee 2008; Gond et al. 2009; Vogel 2005), insofar as the Foucauldian approach we adopt helps define the rules contained in organizational CSR and codes of conduct as discipline or control mechanisms that are constitutive of a mode of domination and normalization (Crane et al. 2008) beyond 
their intrinsic, moral, and normative reasons (Pope and Waeraas 2016). In line with developments that treat CSR as an "instrumental" or "manipulative" strategy justified on economic grounds and utilitarian benefits serving corporate interests (Banerjee 2008; Gond et al. 2009; Vogel 2005), our study extends the view that codes of ethics, through what they include and exclude (i.e., the inclusion-exclusion principle), act as key means through which organizations try to govern behaviors and relationships between their members (Foucault $1965,1970,1973)$. Our case shows that such codes of conduct are a manifestation of the ways the ethical subject is acted on by disciplinary practices and modes of domination, to which he or she directly contributes and participates by following specific uses, by adhering to collective behavioral regularities, and by viewing potential negative effects as normal and classic consequences that are part of a broader system.

\section{Implication 3: A Renewed Conception of Ethics as a Practice of the Self, Based on Ethical Awareness and Self-Reflexivity, Engaged in Relation to Others}

Finally, this research contributes to literature on the ethical responsibilities and moral duties involved in IT uses (Johnson 2015; Martin et al. 2017) by questioning who should be held responsible for employees' technological ill-being and by suggesting the development of ethical behaviors based on awareness and self-reflexivity. Our study highlights, in line with the adopted Foucauldian framework (1985a, 1985b), that beyond practices of domination, an alternative moral project can be envisaged in which ethical behavior entails first analyzing, criticizing, and revealing the regimes of truth that legitimize disciplinary practices. As our case suggests, being a member does not mean simply accepting the formal rhetoric of the organization but also being more reflexive on own constitution.

In particular, our findings show that ubiquitous IT uses imply behaviors that necessitate effective management and, before that, better awareness from a whole community of actors of their potential effects. As a manager in the case suggested, such effective management reveals the need for various organizational stakeholders to develop an awareness of the ethical issues (Foucault 1978, 1985a, 1985b) and appreciate the ethical implications of IT uses (Cordeiro 1997; Tarafdar et al. 2015), by staying alert, communicating clearly, developing an ethical framework, and applying moral reasoning to such issues. These issues are part of the ethical awareness and self-reflexivity that span all members of an organization embedded in broader dialogues about ethical conduct (Herschel and Andrews 1997).

As highlighted in the case, while ethical uses of IT require "good judgment" as the fruit of deliberation and reflexivity (Koehn 1999, p. 67), people's obsession with a culture of immediacy and efficiency, as shown in the case, has reduced their ability to develop sound judgments. Technology has indeed become so integral to people's lives, both professionally and personally - to the point that some people even perceive such IT uses as extensions of their individual bodies (Arnold 2003), as illustrated by the McLuhanesque model of technology (McLuhan 1967), or as a "habitat", as they literally live in their IT (Bellotti et al. 2005) - that it demands a response from everyone, at the same level (both collective and institutional), acknowledging how deeply embedded it is and how it resonates within each individual (Foucault 1984b). Our research thus suggests that a moral dialogue is necessarily rooted in ethical self-awareness. The goal is to realize what happens when people use ubiquitous IT - not to become accustomed to it but "to be re-sensitized" to the effects of their behaviors, actions, and usages; to "reappropriate [their] humanity" (Ellul 1980); and to develop their "imperative of responsibility" (Jonas 1984), so as to "act well" (Koehn 1999).

The Foucauldian perspective developed herein thus suggests an alternative to traditional normative ethical theory (see also Crane et al. 2008), as ethics is neither an absolute, 
transcendental property of the individual (freedom being always enmeshed in a broader frame) nor something that organizations and governments can regulate or control by rules, codes of ethics, charts of conduct, or laws (disciplinary practices being always mediated by individual freedom), as highlighted in the case. Instead, ethics is a practice of the self in relation to others, through which the self endeavors to act as a moral subject. This research thus highlights the importance of grounding ethics in practices and technologies of the self (through self-reflexivity, self-discipline, and self-constraints) rather than organizational rules and interdictions (as shown by the examples of companies such as Atos, Intel, and Volkswagen or French law) that might easily be circumvented and wind up being counterproductive.

\section{Toward a Foucauldian Ethics of Ubiquitous IT Uses in Organizations}

Our research suggests a Foucauldian ethics of ubiquitous IT uses in organizations. Beyond analyzing, criticizing, and reflecting, Foucault (1985a, 1985b) indeed invites us to develop new modes of being and action, through ethical self-engagement (Foucault 1984b), to define the self as a moral agent who acts ethically. Our study highlights that Foucauldian ethics is a conscious practice of the self, at the intersection of the subject's freedom to make choices about who to be and what to do and the organizational context in which those choices are situated, disciplined, and governed (Crane et al. 2008; Ibarra-Colado et al. 2006). The ethical self thus emerges in the relationship between individual morality and organizationally prescribed principles (Ibarra-Colado et al. 2006), subjectivity, and power (Dey and Steyaert 2016), so that the self is both a target of power and the condition of acting differently (Fig. 4).

The study suggests a Foucauldian ethics of IT uses in organizations, which is intertwined in a mutually constitutive relationship between the self, as a moral subject of own actions (responsible IT uses), and broader organizational principles, in which CSR appears as a techne organized through discursive practices. Ethics emerges as practices enacted through awareness (of larger discursive practices), strategies of self-reflexivity, and self-engagement, implying an emotional, embodied, lived experience, rather than an instrumental response to externally constructed values, rules, or injunctions to act in specific ways.

[Insert Figure 4 about here]

Fig. 4 A Foucauldian Perspective on Ethics, IT Uses, and Responsibilities

In particular, Foucault develops a novel reflection on what it means to act ethically, based on four aspects (Foucault 1985a; O'Farrell 2005).

The first aspect entails the part (or the behavior) of the individual that acts as the focus of moral conduct. Our study focuses on the behaviors of individuals while using ubiquitous IT and indicates that using IT ethically always involves (and should involve) self-reflection and engagement, intertwined in a collective, open discussion on which IT uses are desirable and should be encouraged. This discussion is what enables the relationship between the individual and the organization to establish ethical and responsible uses. Employees should be encouraged to use IT ethically and responsibly, in relationships between the self, others, and organizations, in ways that enhance themselves and the general well-being of the organizations of which they are part. 
The second aspect concerns that which makes individuals recognize their moral obligations. A Foucauldian perspective invites people to free their ethical sensibilities through better awareness of modes of subjection, which enables them to recognize the potential negative effects of ubiquitous IT uses. In line with this view, it is incumbent on researchers to give people a view of themselves as having a role to play in such uses and a proportionate level of responsibility for their actions, their well-being, and the well-being of others.

The third aspect refers to the means by which individuals transform and work on themselves. Ethical self-engagement implies novel forms of self-discipline and selfconstraints related to ubiquitous IT uses. As in ancient communities, in which ethical selfengagement relied on self-discipline and constraints (e.g., abstinence, memorization, examination of conscience, meditation, silence, and listening to others), employees should work on themselves, train themselves, and be trained to become ethical subjects, by means of reflexivity through which they can transform themselves (Crane et al. 2008). According to Davies (1995), being human means being engaged with technologies and being able to set limits and say no when necessary.

The fourth aspect involves the individual's aspirations (i.e., what sort of person an individual wants to be). Ethics is thus a work of art, a project of and for the self (Rabinow 1984). The goal of ethical self-engagement is to produce the self in accordance with own aspirations (i.e., the image desired and how life should to be lived). This aspect raises meaningful questions about an employee's role, motivations, and aspirations as an individual embedded in an organization, especially when using ubiquitous IT (e.g., freedom, selffulfillment, compliance, obedience); it also questions his or her responsibility to the community and society while using IT, as this ethos is a way of caring for others (Foucault 1997).

\section{Practical Implications: A Call to Create the Conditions of Self-Engagement, From Desensitization to Re-Sensitizing}

Our research is also a call to action, to rethink and enact IT uses as ethical practices. It calls for a renewed form of ethical self-engagement, to move from desensitization to re-sensitizing. By doing so, this study offers practical implications for employees, IT managers, and executives that help clarify how ubiquitous IT uses and their ethical implications should be governed.

Our study suggests that it is critical to create the conditions of ethical self-engagement by providing an enabling environment that facilitates active, creative awareness and innovative processes of critical reflexivity, sensitization, and self-formation (Crane et al. 2008). Beyond the "head-in-the-hand" syndrome that leads organizations to exclude technological ill-being from their preoccupations, and beyond CSR policies and codes of conduct that organizations use to solve only visible ethical problems, Foucault advises thinking differently and exploring the conditions of freedom or dependence, through a better awareness of modes of subjection embedded in organization discourses and disciplinary practices. Such an environment should enable a better understanding of the potential harmful effects of ubiquitous IT uses (i.e., what technologies can do to you, beyond what they can do for you, as classically studied; Ayyagari et al. 2011) and of their consideration or neglect (and for which purposes) by the organization.

Such awareness also relies on educating employees to think beyond docility and compliance. It implies being cognizant of ethical subjectivity and skeptical in the face of implicit norms of behavior or more formal rules and dictums; it implies working on themselves and learning how to discipline their own behavior, according to their aspirations and goals, in the face of 
formal or informal injunctions to act, behave, and communicate in specific ways. Prior research in MIS has shown that compulsive behaviors, technostress, and harmful impacts on the individual are often due to deficient self-regulation and bad habits (Soror et al. 2012); it is thus incumbent on each individual to be more reflexive on his or her behaviors and on his or her impact on others. For example, employees could engage in actions that help them develop better coping skills, such as adopting a control strategy (Srivastava et al. 2015), by taking part of the workday exclusively for themselves (Ayyagari et al. 2011). Social support (though sensitizing workshops) could also help them better deal with stressful events.

In that regard, IT managers seem responsible for driving formal and informal learning about IT and creating support to help employees regulate their own use of IT. Their role in the selection of technologies needs to evolve, away from the prevailing instrumental emphasis on efficiency or costs, which is no longer sufficient. The value of IT also needs to be measured from an ethical standpoint, through a better awareness of its effects. Technologies should be evaluated in terms of their positive and negative impacts on social relations and potential employees' technological ill-being in organizations. Yet, thus far, such ethical impacts are seldom considered in either academic literature or real-world IT adoption. (Most organizations' responses to prevent health risks in the workplace are primarily directed at physical risks [Ayyagari et al. 2011], not moral or socio-psychological risks.)

This reflection thus should also engage HR managers, who tend to be excluded from IT-based decisions, despite the effects of IT uses on employees' well-being. HR managers should be sensitized to their responsibility to ensure that employees do not experience dark-side IT use effects. However, this point also raises the question of the extent to which organizations, managers, and users actually have tools to measure, evaluate, and manage technological illbeing. In addition, managers' role should no longer constrain and discipline IT uses, especially in a context of IT consumerization, but instead help users make the most efficient choices regarding the IT they can use, by training them to manage their freedom and educating them about the stakes and consequences of their choices (Leclercq-Vandelannoitte and Bertin 2018).

Concretely, managers must be consistent, communicate clearly, stay alert, promote an inspiring digital culture, and lead by example, by limiting unnecessary and less urgent uses of ubiquitous IT outside working hours, thus relieving the pressure of constantly checking, encouraging employees to reflect on how they use IT from work and from other spaces, and prompting the development of respectful work practices. To that end, it is up to managers to create an ethical climate that encourages employees to understand what is at stake when they use IT for work and to discuss and share their IT-related experiences. Overall, the maturation of ubiquitous IT uses in organizations demands better internal coordination, across projects and functions.

\section{Limitations and Avenues for Research: Shaking Minds through Better Awareness, Reflexivity, and Self-Engagement}

This study includes several limitations. From a conceptual standpoint, this paper is framed within the work of Foucault, whose concepts tend to be complex and difficult to operationalize in contemporary organizations, especially considering that Foucault, consistent with his line of thought, refused to specify clear rules for action, normative prescriptions, or practical recipes for how to act and behave.

From an empirical standpoint, this research offers only one illustration of the ethical concerns raised by the potential harmful effects of ubiquitous IT uses. Our instrumental case study 
might not be considered typical of other cases (Stake 2003). The findings might have differed if other companies (in the automotive industry and other fields) had been investigated and if different organizational contexts and types of activities and managerial roles had been explored (Pinsonneault and Rivard 1998). Furthermore, the empirical study did not account for applications such as Social Messenger, WhatsApp, or Telegram, which were not used as organizational tools in 2014, though they were certainly used informally by some employees.

However, despite these limitations, the results, based on a Foucauldian framework, could be further investigated or applied to other contexts or ethical issues. Compared with a classic conception of ethics (Crane et al. 2008), the Foucauldian conceptualization of ethics, which treats CSR policies as a mode of domination and normalization and invites educating people to become ethical subjects, suggests an original research program that opens new avenues for theory and research.

In particular, our study calls for extending the critical CSR approach to explore in greater depth the inclusion-exclusion principle in CSR policies to understand what they actually mean and imply for organizational actors. We also call for developing a more comprehensive framework of IT uses that incorporates their ethical implications (Martin and Freeman 2003). Such efforts should explore sociological and micro-mechanisms of the links among IT, ethics, and corporate responsibility (Hinings and Greenwood 2002; Powell and Colyvas 2008), with the objective to help companies and the community identify and anticipate ethical organizational responsibilities and individual accountability (Leclercq-Vandelannoitte and Bertin 2018) and act accordingly (De George 2000). Given the potential effects of ubiquitous IT uses, it is critical to investigate new solutions to govern their uses and ethical implications, as shown in the case, which implies shaking minds through better awareness, reflexivity, and self-engagement.

In conclusion, guided by a Foucauldian framework, this research identifies the persistent gap, in both ethics literature and practice, between technology and ethics, which is widening exponentially (Marshall 1999). This abdication of responsibility is critical, because the failure to adopt a broad social consensus on appropriate uses of technology may cause ruptures in individual well-being and social conflicts. Considering the deeply harmful impacts of ubiquitous IT uses, it is incumbent on business ethicists and practitioners to assess the ethical challenges they raise for society, organizations, and employees (De George 1999) — especially because stressful IT situations happen to both experienced and inexperienced users (Liang and Xue 2009) and such technologies affect not only professional aspects but potentially any aspect of people's lives. It is thus essential to invent new ways of being and engaging, to resist or shape them, as much as people are shaped by them (Serres 2015). Ultimately then, society may benefit from technologies in a responsible way. Doing so demands new ways of thinking and acting, to help people know how they can live better with these technologies (Koehn 1999) and reappropriate their humanity (Ellul 1980).

\section{Compliance with Ethical Standards:}

Ethical approval: This article does not contain any studies with animals performed by any of the authors.

Informed consent: Informed consent was obtained from all individual participants included in the study. 


\section{References}

Acquier, A., \& Gond, J.-P. (2007). Aux Sources de la Responsabilité Sociale de l'Entreprise: (Re)Lecture et Analyse d'un Ouvrage Fondateur: Social Responsibilities of the Businessman d'Howard Bowen (1953), Finance Contrôle Stratégie, 10(2), 5-35.

Addas S., \& Pinsonneault A. (2015). The many faces of IT interruptions: A taxonomy and preliminary investigation of their performance effects. Information Systems Journal, 25, 231273.

Alder, G. S. (1998). Ethical issues in electronic performance monitoring: A consideration of deontological and teleological perspectives. Journal of Business Ethics 17(7), 729-743.

Agence France-Presse (2016, December 31). French workers win legal right to avoid checking work email out-of-hours. Retrieved from https://www.theguardian.com/money/2016/dec/31/french-workers-win-legal-right-to-avoidchecking-work-email-out-of-hours.

Arnold, M. (2003). On the phenomenology of technology: The "Janus-faces" of mobile phones. Information and Organization, 13(4), 231-256.

Ayyagari, R., Grover, V., \& Purvis, R. (2011). Technostress: Technological antecedents and implications. MIS Quarterly, 35(4), 831-858.

Banerjee, S. B. (2008). Corporate social responsibility: The good, the bad and the ugly. Critical Sociology, 34(1), 51-79.

Barley, S. R., Meyerson, D. E., \& Grodal, S. (2011). E-mail as a source and symbol of stress. Organization Science, 22(4), 887-906.

Bauman, Z., \& Lyon, D. (2013). Liquid surveillance: A conversation. New York: Wiley.

Bellotti, V. et al. (2005). Quality versus quantity: E-mail-centric task management and its relation with overload. Human-Computer Interaction, 20(1), 89-138.

Booth, F. (2014, June 13). How to do a digital detox. Forbes. Retrieved from https://www.forbes.com/sites/francesbooth/2014/06/13/how-to-do-a-digitaldetox/\#5d6eaa9c65a4.

Borgman, A. (1992). Crossing the postmodern divide. Chicago: University of Chicago Press.

Braverman, H. (1998 [1974]). Labor and monopoly capital: The degradation of work in the twentieth century. New York: Monthly Review Press.

Buchholz, R., \& Rosenthal, S. (2002). Technology and business: Rethinking and moral dilemma. Journal of Business Ethics, 41, 45-50.

Burkus, D. (2016, July 12). Why Atos Origin is striving to be a zero-email company. Forbes. Retrieved from https://www.forbes.com/sites/davidburkus/2016/07/12/why-atos-origin-isstriving-to-be-a-zero-email-company/\#56f2fee08d0f.

Burrell, G. (1988). Modernism, post modernism and organizational analysis 2: The contribution of Michel Foucault. Organization Studies, 9(2), 221-235.

Capra, R., Khanova, J., \& Ramdeen, S. (2013). Work and personal e-mail use by university employees: PIM practices across domain boundaries. Journal of the American Society for Information Science and Technology, 64(5), 1029-1044.

Cordeiro W.P. (1997). Suggested management responses to ethical issues raised by technological change. Journal of Business Ethics. 16, 1393-1400. 
Cousteaux, A. S., PanKéShon J. L., \& Jacobs, A. (2010). Is Ill-being gendered? Suicide, risk for suicide, depression and alcohol dependence. Revue française de sociologie, 51, 3-40.

Crane, A., Knights, D., \& Starkey, K. (2008). The conditions of our freedom: Foucault, organization, and ethics. Business Ethics Quarterly, 18(3), 299-320.

Cunha, J., Carugati A., \& Leclercq-Vandelannoitte, A. (2015). The dark side of computermediated control. Information Systems Journal, 25(4), 319-354.

D'Arcy, J., Gupta, A., Tarafdar, M., \& Turel, O. (2014). Reflecting on the "Dark Side" of information technology use. Communications of the Association for Information Systems, 35(1), 109-118.

Davies, P.W. F. (1995). Managing technology: Some ethical preliminaries. Business Ethics 4(3), 130-138.

Davies, P. W. F. (1997). Technology and business ethics theory. Business Ethics: A European Perspective, 6(2), 76-80.

Davis, K., \& Blomstrom, R.L. (1966). Business and its environment. New York: McGrawHill.

De George, R. T. (1999). Business ethics and the information age. Business and Society Review, 104 (3), 261-278.

De George, R. T. (2000). Ethics and the challenge of the information age. Business Ethics Quarterly, 10(1), 63-72.

Dery, K., Kolb, D., \& MacCormick J. (2014). Working with connective flow: How smartphone use is evolving in practice. European Journal of Information Systems, 23, 558570.

Dey, P., \& Steyaert, C. (2016). Rethinking the space of ethics in social entrepreneurship: Power, subjectivity and practices of freedom. Journal of Business Ethics, 133(4), 627-641.

Drake, B., Yuthas, K., \& Dillard, J. F. (2000). It's only words: Impacts of information technology on moral dialogue. Journal of Business Ethics, 23(1), 41-59.

Dubois, A., \& Gadde, L.-E. (2002). Systematic combining: An abductive approach to case research. Journal of Business Research, 55(7), 553-560.

Eisenhardt, K. M. (1989). Building theories from case study research. Academy of Management Review 14(4), 532-550.

Ellul, J. (1980). The ethics of non-power. In Kranzberg, M. (Ed.), Ethics in an age of pervasive technology (pp. 204-212). Boulder, CO: Westview Press.

Factor, R., Oliver, A. L., \& Montgomery, K. (2013). Beliefs about social responsibility at work: comparisons between managers and non-managers over time and cross-nationally. Business Ethics: A European Review, 22(2), 143-158.

Foucault, M. (1965). Madness and civilization. New York: Pantheon.

Foucault, M. (1970). The order of things. An archaeology of the human sciences. London: Tavistock Publications.

Foucault, M. (1973). The birth of the clinic. An archaeology of medical perception. London: Routledge.

Foucault, M. (1978). The history of sexuality. Volume 1: An introduction. New York: Pantheon Books. 
Foucault, M. (1979). Discipline and punish. Harmondsworth: Penguin.

Foucault, M. (1983). The subject and power. In H. Dreyfus \& P. Rabinow (Eds.), Michel Foucault: Beyond structuralism and hermeneutics (2nd ed., pp. 208-228). Chicago: University of Chicago Press.

Foucault, M. (1984a). Space, knowledge and power. In Paul Rabinow (Ed.) The Foucault reader (pp. 239-256). New York: Pantheon.

Foucault, M. (1984b). The ethics of the concern for self as a practice of freedom. In P. Rabinow (Ed.), Ethics, subjectivity and truth (281-301). New York: The New Press.

Foucault, M. (1985a). The use of pleasure: the history of sexuality, Volume 2. New York: Pantheon Books.

Foucault, M. (1985b). The care of the self: the history of sexuality, Volume 3. New York: Pantheon Books.

Foucault, M. (1997). Ethics: Subjectivity and truth. London: Allen Lane.

Gond, J.-P., \& Moon, J. (2011). Corporate social responsibility in retrospect and prospect: exploring the life-cycle of an essentially contested concept. In J.-P. Gond, \& J. Moon (Eds.), Corporate social responsibility: A reader (Vol. 1, pp. 1-28). New York: Routledge.

Gond, J.-P., Palazzo, G., \& Basu, K. (2009). Reconsidering instrumental corporate social responsibility through the mafia metaphor, Business Ethics Quarterly, 19(1), 57-85.

Harnish, V., (2014). Five ways to liberate your team from email overload. Fortune, (16 June), 52.

Herschel, R. T., \& Andrews, P. H. (1997). Ethical implications of technological advances on business communications. Journal of Business Communication, 34(2), 160-170.

Hinings, C. R., \& Greenwood, R. (2002). Disconnects and consequences in organization theory. Administrative Science Quarterly, 47(3), 411-421.

Ibarra-Colado E., Clegg, S., Rhodes, K., \& Kornberger, M. (2006). The ethics of managerial subjectivity. Journal of Business Ethics, 64, 45-55.

Johnson, D. G. (2015). Technology with no human responsibility? Journal of Business Ethics, 127(4), 707-715.

Jonas, H. (1984). The imperative of responsibility: In search of an ethics for the Technological Age. Chicago: University of Chicago Press.

Koehn, D. (1999). Ethics in a technological age. Business and Society Review, 104(1), 57-90.

Kolb, D., Caza, A., \& Collins, P. (2012). States of connectivity: New questions and new directions. Organization Studies, 33(2), 267-273.

Laval, C. (2015, May 04). Du "zéro email" à la "social collaboration". Journal du Net. Retrieved from https://www.journaldunet.com/solutions/expert/60798/du--zero-email--a-la-social-collaboration.shtml.

Leclercq-Vandelannoitte, A. (2011). Organizations as discursive constructions: A Foucauldian approach. Organization Studies, 32(9), 1247-1271.

Leclercq-Vandelannoitte, A., \& Bertin, E. (2018). Who governs IT nowadays? From sovereign IT governance to liberal IT governmentality: A Foucauldian analogy. European Journal of Information Systems, 27(3), 326-346. 
Liang, H., \& Xue, Y. (2009). Avoidance of information technology threats: A theoretical perspective. MIS Quarterly, 33(1), 71-90.

Loacker, B., \& Muhr, S. L. (2009). How can I become a responsible subject? Towards a practice-based ethics of responsiveness. Journal of Business Ethics, 90, 265-277.

MacCormick, J., Dery, K., \& Kolb, D. (2012) Engaged or just connected? Smartphones and employee engagement. Organizational Dynamics, 41(3), 194-201.

Markus, M. L. (1994). Electronic mail as the medium of managerial choice. Organization Science, 5(4), 502-527.

Marshall, K. P. (1999). Has technology introduced new ethical problems? Journal of Business Ethics, 19(1), 81-90.

Martin, K., \& Freeman, R. E. (2003). Some problems with employee monitoring. Journal of Business Ethics, 43(4), 353-361.

Martin, K., \& Freeman, R. E. (2004). The separation of technology and ethics in business ethics. Journal of Business Ethics, 53, 353-364.

Martin, K., Shilton, K., \& Smith J., (2017). Call for papers, special issue of the Journal of Business Ethics, technology, ethics, and corporate responsibility. Retrieved from http://static.springer.com/sgw/documents/1584272/application/pdf/Special+Issue+-

+Martin+et+al+Technology\%2C+Ethics\%2C+and+Corporate+Responsibility.pdf.

Mazmanian, M., Orlikowsi, W. J., \& Yates, J., (2013). The autonomy paradox: The implications of mobile devices for knowledge professionals. Organization Science, 24(5), 1337-1357.

McLuhan, M. (1967). Understanding media: the extension of man. London: Sphere Books.

Miles M., \& Huberman, M. (1994). Qualitative data analysis. Beverly Hills, CA: Sage.

O'Farrell, C. (2005). Michel Foucault. London: Sage.

Ogburn, W. F. (1966). Social change with regard to cultural and original nature. New York: B. W. Huebsch.

Ottensmeyer, E. J., \& Heroux, M. A. (1991). Ethics, public policy, and managing advanced technologies: The case of electronic surveillance. Journal of Business Ethics, 10(7), 519-526.

Petroff, A., \& Cornevin, O. (2017, January 2). France gives workers 'right to disconnect' from office email. Retrieved from http://money.cnn.com/2017/01/02/technology/france-officeemail-workers-law/index.html.

Pinsonneault, A., \& Rivard, S. (1998). Information technology and the nature of managerial work: From the productivity paradox to the Icarus paradox?. MIS Quarterly, 22, 287-311.

Pope, S., \& Waeraas, A. (2016), CSR-washing is rare: A conceptual framework, literature review, and critique. Journal of Business Ethics, 137(1), 173-193.

Powell, W. W., \& Colyvas, J. (2008). Microfoundations of institutional theory. In R. Greenwood, C. Oliver, K. Sahlin, \& R. Suddaby (Eds.), The Sage handbook of organizational institutionalism (pp. 276-298). London: Sage.

Rabinow, P. (Ed.). 1984. The Foucault reader. Harmonsdsworth: Penguin.

Ragu-Nathan, T.S., Tarafdar, M., Ragu-Nathan, B.S., \& Tu, Q. (2008). The consequences of technostress for end users in organizations: Conceptual development and empirical validation. Information Systems Research, 19(4), 417-433. 
Rasche, A., Morsing, M., \& Moon, J. (2017). Corporate social responsibility: Strategy, communication, governance. Cambridge: Cambridge University Press.

Richards, L. (2005). Handling qualitative data: A practical guide. London: Sage.

Serenko, A., \& Turel, O., (2015). Integrating Technology Addiction and Use: An Empirical Investigation of Facebook Users. AIS Transactions on Replication Research, 1(2), 1-18.

Serres, M. (2015). Le gaucher boiteux: puissance de la pensée. Paris: Edition le Pommier.

Sewell, G., \& Taskin, L., (2015). Out of sight, out of mind in a new world of work? Autonomy, control, and spatiotemporal scaling in telework. Organization Studies, 36(11), 1507-1529.

Solomon, R. C., \& Hanson, K. (1985). It's good business. New York: Harper \& Row.

Soror, A. A., Steelman, Z. R., \& Limayem, M. (2012). Discipline yourself before life disciplines you: Deficient self-regulation and mobile phone unregulated use. In 45th Hawaii International Conference on System Science (pp. 849-858).

Soror, A.A., Hammer, B.I., Steelman, Z.R., Davis, F.D., \& Limayem, M.M. (2015). Good habits gone bad: Explaining negative consequences associated with the use of mobile phones from a dual-systems perspective. Information Systems Journal, 25, 403-427.

Spira, J. B. (2011). Overload! How too much information is hazardous to your organization. New York: Wiley.

Srivastava, S.C., Chandra, S., \& Shirish, A. (2015). Technostress creators and job outcomes: theorising the moderating influence of personality traits. Information Systems Journal, 25, $355-401$.

Stake, R.E. (2003). Case studies. In N.K. Denzin \& Y. Lincoln (Eds.), Strategies of qualitative inquiry (pp. 134-164). London: Sage.

Starkey, K., \& Hatchuel, A. (2002). The long detour: Foucault's history of desire and pleasure. Organization, 9(4), 641-656.

Steelman, Z. Soror, A., Limayem, M., \& Worrell, D. (2012). Obsessive compulsive tendencies as predictors of dangerous mobile phone usage. In AMCIS 2012 Proceedings 9. http://aisel.aisnet.org/amcis2012/proceedings/HCIStudies/9.

Tarafdar, M, D'Arcy, J, Turel, O and Gupta, A. (2015). The dark side of information technology. MIT Sloan Management Review, 56 (2), 61-70.

Tarafdar, M., Pullins, E.B., \& Ragu-Nathan, T.S. (2014). Techno-stress: Negative effect on performance and possible mitigations. Information Systems Journal, 25(2), 103-132.

Tarafdar, M., Gupta, A., \& Turel, O. (2013). The dark side of information technology use. Information Systems Journal, 23(3), 269-275.

Tarafdar, M., Tu, Q., Ragu-Nathan, B.S., \& Ragu-Nathan, T.S. (2007). The impact of technostress on role stress and productivity. Journal of Management Information Systems, 24(1), 301-328.

Turel, O., Serenko, A., \& Giles, P. (2011) Integrating technology addiction and use: An empirical investigation of online auction users. MIS Quarterly, 34, 1043-1061.

Vogel, D. (2005). The market for virtue. The potential and limits of corporate social responsibility. Washington, DC: Brookings institution Press. 
Weaver, G. R., Treviño, L. K., \& Cochran, P. L. (1999). Integrated and decoupled corporate social performance: management commitments, external pressures, and corporate ethics practices. Academy of Management Journal, 42(5), 539-552.

Willcocks L. (2004). Foucault. Power/knowledge and information systems: Reconstructing the present. In J. Mingers \& L. Willcocks (Eds.), Social theory and philosophy for information systems. New York: Wiley.

Windsor, D. (2006). Corporate social responsibility: Three key approaches. Journal of Management Studies, 43(1), 93-114.

Wood, D. J. (1991). Corporate social performance revisited. Academy of Management Review, 16(4), 691-718. 


\begin{tabular}{|l|l|l|}
\hline $\begin{array}{c}\text { Core notions } \\
\text { Martin and Freeman } \\
\text { 2003) }\end{array}$ & \multicolumn{1}{|c|}{ Questions } & \multicolumn{1}{|c|}{ Potential impacts of ubiquitous IT use } \\
\hline Freedom & $\begin{array}{l}\text { How might ubiquitous IT uses } \\
\text { affect employees basic } \\
\text { liberties? }\end{array}$ & $\begin{array}{l}\text { Autonomy paradox } \\
\text { Collective expectations of accessibility and availability } \\
\text { Constant connectivity and widespread work } \\
\text { interruptions } \\
\text { Dependence and addiction } \\
\text { Loss of freewill }\end{array}$ \\
\hline Privacy & $\begin{array}{l}\text { How might ubiquitous IT uses } \\
\text { affect employees sense of } \\
\text { control and privacy? }\end{array}$ & $\begin{array}{l}\text { Intrusiveness } \\
\text { Loss of privacy and sense of control of one's actions } \\
\text { Constant reachability } \\
\text { Irony of extension and invasion of private spheres } \\
\text { Technostress } \\
\text { Control of employees' engagement }\end{array}$ \\
\hline Respect & $\begin{array}{l}\text { How might ubiquitous IT uses } \\
\text { affect the treatment of } \\
\text { employees as ends or means? }\end{array}$ & $\begin{array}{l}\text { Janus-faced (ironic, perverse, and paradoxical) effects } \\
\text { Obsession with efficiency, cult of urgency, and } \\
\text { productivity regardless of those affected } \\
\text { Embeddedness in a broader culture rewarding total } \\
\text { engagement and connection } \\
\text { Potential degradation of working conditions }\end{array}$ \\
\hline
\end{tabular}

Table 1 Synthesis of the impacts of ubiquitous IT uses on freedom, privacy, and respect 


\begin{tabular}{|l|l|l|}
\hline & \multicolumn{1}{|c|}{ Definition } & \multicolumn{1}{c|}{ Heuristic power } \\
\hline $\begin{array}{l}\text { Techne as } \\
\text { practical rationality }\end{array}$ & $\begin{array}{l}\text { A practical rationality governed by a } \\
\text { conscious aim, purposefully organized } \\
\text { through discursive practices. }\end{array}$ & $\begin{array}{l}\text { Enables understanding of the construction } \\
\text { of social reality through power relations, } \\
\text { and grasping of the practical rationality } \\
\text { behind specific practices (e.g., the } \\
\text { consideration, though inclusion or } \\
\text { exclusion, in organizational practice and } \\
\text { codes of ethics of issues of technological } \\
\text { ill-being); enables a better understanding } \\
\text { of the conscious or unconscious aims and } \\
\text { power relations behind such practices. }\end{array}$ \\
\hline Awareness & $\begin{array}{l}\text { Knowledge of and strategies of reflexivity } \\
\text { people's present circumstances, } \\
\text { ondition, subjection practices, and } \\
\text { embeddedness in power relations. }\end{array}$ & $\begin{array}{l}\text { Enables exploration of people's awareness } \\
\text { af and reflexivity on their condition and } \\
\text { circumstances in which they evolve } \\
\text { (related, for example, to the potential } \\
\text { harmful effects of excessive ubiquitous IT } \\
\text { uses at work and ill-being). }\end{array}$ \\
\hline Self-engagement & $\begin{array}{l}\text { Questions of responsibilities; constitution } \\
\text { of new modes of being through ethics, } \\
\text { technologies of the self, and care of the } \\
\text { self. }\end{array}$ & $\begin{array}{l}\text { Enables questioning of moral and ethical } \\
\text { responsibilities and accountabilities } \\
\text { (regarding employees'technological ill- } \\
\text { being, for example) and exploration of } \\
\text { questions of individual and collective care } \\
\text { and engagement. }\end{array}$ \\
\hline
\end{tabular}

Table 2 A synthesis of the heuristic power of Foucauldian concepts to grasp relationship between ethics and responsibilities 


\begin{tabular}{|c|c|c|}
\hline \multicolumn{2}{|r|}{ Kinds of data } & Description and goal \\
\hline \multirow{3}{*}{$\begin{array}{l}\text { Primary } \\
\text { data }\end{array}$} & Semi-directive interviews & $\begin{array}{l}14 \text { semi-structured interviews with the manager and salespeople, } \\
\text { other managers (directors of business units), CSR manager, IT } \\
\text { manager, and HR manager, to explore ubiquitous IT uses and } \\
\text { ethical implications and consideration of such issues in CSR. }\end{array}$ \\
\hline & $\begin{array}{l}\text { Direct field observations; } \\
\text { written report of a typical } \\
\text { workday and communication } \\
\text { practices }\end{array}$ & $\begin{array}{l}\text { Observation of work and communication practices of a } \\
\text { commercial team located in different European countries and led } \\
\text { by a manager (director for several client accounts in Europe) to } \\
\text { glean better insight into their uses of ubiquitous IT. }\end{array}$ \\
\hline & $\begin{array}{l}\text { Follow-up informal } \\
\text { interviews and meetings }\end{array}$ & $\begin{array}{l}\text { Exploration of possible evolutions of practices and perceptions, } \\
\text { collection of additional feedback. }\end{array}$ \\
\hline \multirow{2}{*}{$\begin{array}{l}\text { Secondary } \\
\text { data }\end{array}$} & $\begin{array}{l}\text { Internal documents related } \\
\text { to the CSR policy (e.g., } \\
\text { "code of ethics and } \\
\text { conduct") Internal charts }\end{array}$ & $\begin{array}{l}\text { Analysis of the CSR policy (covered domains, values, } \\
\text { objectives, measures, communication activities, relationship } \\
\text { between IT uses and ethics). }\end{array}$ \\
\hline & $\begin{array}{l}\text { Press releases about the } \\
\text { national regulatory contexts }\end{array}$ & $\begin{array}{l}\text { Contextualization. } \\
\text { Update of findings and observations. }\end{array}$ \\
\hline
\end{tabular}

Table 3 Synthesis of collected data 


\begin{tabular}{|c|c|c|}
\hline $\begin{array}{l}\text { Three-step coding } \\
\text { procedure }\end{array}$ & Definition & Application to our case study \\
\hline $\begin{array}{l}\text { 1. Descriptive } \\
\text { coding }\end{array}$ & $\begin{array}{l}\text { Storing information } \\
\text { that describes the } \\
\text { case }\end{array}$ & $\begin{array}{l}\text { Description of the function and role of respondents; } \\
\text { description of IT deployed and uses; description of } \\
\text { organizational design, work activities, and communication } \\
\text { practices; description of the CSR policy. }\end{array}$ \\
\hline 2. Topic coding & $\begin{array}{l}\text { Allocating passages } \\
\text { to topics that } \\
\text { correspond to } \\
\text { conceptual entities }\end{array}$ & $\begin{array}{l}\text { Specification of the work practices and uses of ubiquitous } \\
\text { IT; identification of potential ethical effects raised by } \\
\text { ubiquitous IT uses (liberty, privacy, respect, and } \\
\text { responsibilities; Martin and Freeman 2003); identification of } \\
\text { inclusion or exclusion practices of IT-issues in CSR policy. }\end{array}$ \\
\hline $\begin{array}{l}\text { 3. Analytical } \\
\text { coding }\end{array}$ & $\begin{array}{l}\text { Defining and } \\
\text { interpreting the } \\
\text { meaning of extracts } \\
\text { in context }\end{array}$ & $\begin{array}{l}\text { Analysis of the construction of a discourse on CSR; analysis } \\
\text { of the rationality, power relations, and goals developed in } \\
\text { such a discourse; assessment of the various consequences of } \\
\text { the practice of ubiquitous IT uses and the potential ethical } \\
\text { issues they raised; assessment of management and } \\
\text { employees' awareness and consideration of such effects; } \\
\text { analysis of the relationship between the organization's } \\
\text { corporate and managerial responsibilities with IT uses; } \\
\text { analysis of the emergence of different forms of ethical } \\
\text { engagement. }\end{array}$ \\
\hline
\end{tabular}

Table 4 Synthesis of the thematic coding procedure 


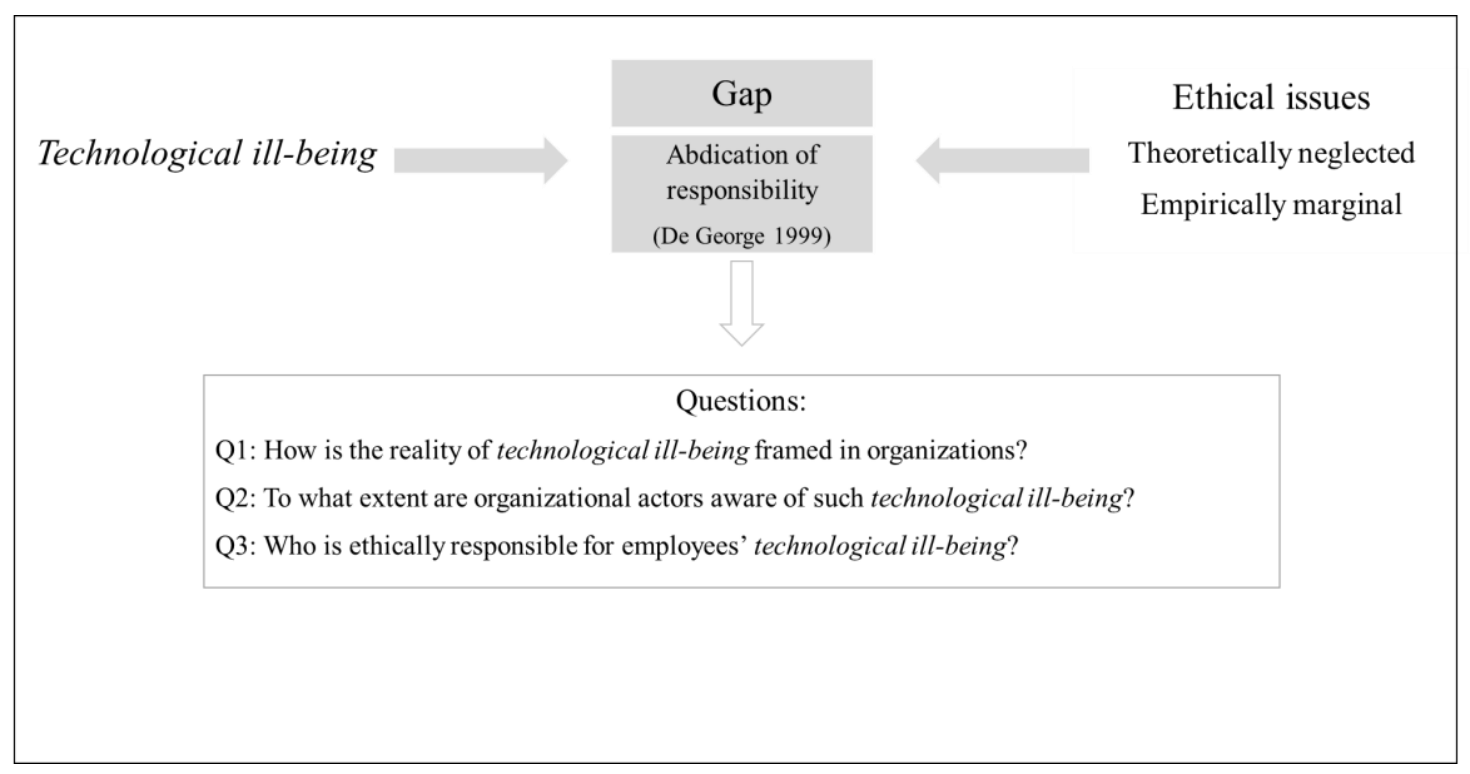

Fig. 1 A synthetic view of the abdication of responsibility on technological ill-being 